Original Research Paper

\title{
"Fruits are Results": On the Interaction between Universal Archi-Metaphors, Ethno-Specific Culturemes and Phraseology
}

\author{
Antonio Pamies, Lei Chunyi and Margaret Craig \\ Department of General Linguistics, University of Granada, Spain
}

\author{
Article history \\ Received: 07-05-2015 \\ Revised: 09-06-2015 \\ Accepted: 09-06-2015 \\ Corresponding Author: \\ Antonio Pamies \\ Department of General \\ Linguistics, University of \\ Granada, Spain \\ antonio.pamies@gmail.com
}

\begin{abstract}
This paper deals with the relation between language, culture and reality, as it manifests itself in figurative words, idioms and proverbs involving the concept of FRUIT in several language families. Some productive metaphoric macro-models are identified and analysed, archimetaphors as well as culturemes, analysing how the "experiential" and "cultural" motivational backgrounds can interact. We also investigate how grammatical metaphors depend on the underlying images and how cognitive mappings can be reversed.
\end{abstract}

Keywords: Metaphor, Cultureme, Phraseology, Ethnobotanics, Fruit

\section{Introduction}

This paper deals with the relation between language, culture and reality, as it manifests itself in figurative words, idioms and proverbs involving the concept of FRUIT, which works as an iconic model and as a cultureme, both on the level of the source and target domains of figurative expressions. The aim is to investigate, in different languages, some semantic and syntactic differences between potentially universal archimetaphors and ethno-specific culturemes and, at the same time, to show that both categories may sometimes cooperate. Some productive metaphoric macro-models have been identified in several languages and cultures from Europe (Western, Southern and Eastern), Latin America, Middle East, Oceania and China. As a secondary goal, we investigate the influence of the semantic motivation on the syntactic restrictions into idiomatic constructional patterns.

Section 1 opposes archi-metaphors and culturemes in theoretical phraseology. Sections 2, 3 and 4 analyze three productive archi-metaphors involving a fruit as a source domain, from a semantic and grammatical point of view (FRUITS ARE RESULTS, FRUITS ARE OFFSPRING, FRUITS ARE MOMENTS). Section 5 analyzes how culturally-bound metaphors attribute positive or negative connonations to a given fruit in different languages. Section 6 analyzes the reversal of the mapping, showing that the majority of fruit names are themselves metaphors and that their motivational background can be also "experiential", "cultural", or an interaction of both.

\section{Universal Vs. Ethno-Specific Metaphoric Models}

Since phraseological units are as numerous as words, probably more (Gross, 2012), their syntax and semantics should be described as a sub-system with its own level of linguistic analysis (Kunin, 1996; Mejri, 2006: 218). As far as semantics is concerned, an important analytical tool is the Conceptual Metaphor Theory (Lakoff and Johnson, 1980), which allows us to analyze idiomatic meanings in a more systematic way than the traditional "atomized" treatment of figurative phrasemes, viewed as marginal exceptions, more or less picturesque and unpredictable. The undeniable contribution of cognitive approaches to phraseological studies was mainly orientated to metaphoric mappings with an experiential and/or perceptive background, such as up is good/down is bad; discussion is a war; etc, (Mellado Blanco, 2004; Gibbs, 2007). Later, attention was more focused on semantic models whose productivity depends on a culturally-bound basis (Dobrovol'skij and Piirainen, 2005), connecting language and the world vision embedded in each culture, according to the Russian neoHumboldtian linguo-culturological tradition, but essentially focused on idioms and proverbs (Teliya, 1998; Dobrovol'skij, 1998; 2000; Piirainen, 2008; Luque Durán, 2007; Pamies, 2007; 2008; 2011; Pamies and Tutáeva, 2010; Luque Durán and Luque Nadal, 2008, among others). On the other hand, there is a tight relation between the semantic metaphoricity of idioms and their constructional defectivity; phrasemes can even been 
defined as grammatical metaphors where constructions behave like units (Pamies, 2013).

On the one hand, conceptual metaphor is a mental process underlying thousands of particular figurative expressions derived from a reduced number of concrete source domains: A few basic human activities (eating, drinking, moving, hunting, fighting, trading...) behave as mental representations of a huge variety of other phenomena, producing systematic associative patterns, called archi-metaphors (Pamies, 2001; Iñesta and Pamies, 2002) or macro-metaphorical conceptual models (Zykova, 2014a; 2014b). For example, a set of 2,400 English figurative idioms related to COMMUNICATION can be classified into only 11 metaphoric models (Zykova, 2014b: 95-96). On the other hand, culturally-bound metaphors appear when a language assigns a secondary semiotic role to a previous extralinguistic cultural symbol (Dobrovol'skij, 1998; 2000), whose linguistic productivity is attested by its role in figurative language within the limits of a cultural community. For example, many Spanish idioms are metaphors based on bullfighting: sp. conocer el percal, entrar al trapo, cambiar de tercio, dar la puntilla, cortarse la coleta, etc. (cf. Luque Durán et al., 1998). These expressions reflect a given collective world-view by means of linguo-cultural symbols called culturemes (Pamies, 2007; 2008; 2011; Luque Nadal, 2009), which provide specific mental images (Dobrovol'skij, 1998), forming networks of associated ideas (cf. Zykova, 2014b: 94). However, some culturemes may be supranational (Xatara and Seco, 2014: 504) and even international, like the widely spread idioms, based on the Bible or Greek mythology (Piirainen, 2010).

An example of perceptive archi-metaphor would be the model A DRUNKEN PERSON IS AN ANIMAL, underlying idioms like: Eng. drunk as a sow /drunk as a dancing pig /drunk as a monkey /drunk as a fish, etc. (Pamies et al., 2007). Cross-linguistic comparison shows more coincidences than differences, which affect only the choice of the animal while the conceptual mapping between conceptual domains remains the same. For example some Guaraní idioms for "being drunk" are: Grn. huguy jaguarete (*to have jaguar's blood), huguy ka'i (*to have monkey's blood), ojupi hese tahyire (*black ants are climbing on him), otéhe oúvo ñandúicha (*to knit like a spider), tuichaite lembu reve (*to be with a big beetle); opepe (*to flap one's wings in vain), etc. (Pamies et al., 2004). By contrast, culturemes connect DRUNKENNESS with less concrete and transparent references, such as the catholic rites of Holy Week used as a reference in Spanish idioms, like sp. hacer penitencia (*to make penance), hacer las estaciones (*to make the Stations), hacer el viacrucis (*to make the Stations of the Cross), cantarle a la virgen (*to sing for the Virgin), visitar sagrarios (*to visit tabernacles), ponerse más morado que la túnica del Nazareno (to become more purple than the Nazarethian's tunic) (Pamies et al., 2007).

Both concepts, archi-metaphors and culturemes, are complementary to each other, since they have different kinds of motivations. However, some "blending" between these two mechanisms can also be observed, because an archi-metaphor functioning in several languages can be quantitatively dominant in one of them while scarcely productive in another one, or undergo local adaptations that are culturally mediated. The quantitative perspective has been studied by Zykova (2014a): Among thousands of English and Russian figurative idioms based on communication, the archi-metaphor COMMUNICATING IS PLAYING is statistically dominant in English, while, in Russian, the dominant model is COMMUNICATING IS TRAVELLING AND different cultural perceptions may motivate such quantitative differences.

The qualitative interaction, which is the main topic of this research on FRUITS, merges both processes, making their boundaries become at times fuzzy. For example the model DEATH IS A MOVEMENT OF THE LEG is productive in several languages: sp. estirar la pata [*to stretch the $\mathrm{leg}]=$ it. stendere le gambe $=$ stendere le zampe $[*$ to stretch the legs] $=$ pt. esticar a canela $[*$ to stretch the leg] = bater as botas [*to flap one's boots] = eng. to kick the bucket: "To die". As a consequence of rigor mortis, horses, donkeys or cows, stretch their leg(s) when they die, so this model is an experiential archi-metaphor, though not transparent nowadays. However, the Zarma Songhay variant of this image says à nà ázáw zi [*he kicked towards the West] "he died" (Niandou, 1997), therefore, since Muslims are buried with their head towards Mecca, the image of an African "kicking towards the West" merges the previous conceptual metaphor with a local cultureme. The same can be said for the Cantonese idiom (Taishan dialect) ctn. căi le $y \bar{\imath}$ $b o ̀ j i h u \bar{l}$ 踩了一簸箕灰 [*to stick one's foot into the ash collector] "to die", mixing the image of the leg movement with the Buddhist rite of cremation and the Cantonese tradition of burning with the corpse a special kind of bank note called zhř qián纸钱 [*paper money]. According to a superstition, if someone steps on these ashes he will die soon.

\section{The Metaphoric Model Fruits are Results}

\section{Conceptual Mappings}

Fruits have many figurative denominations, the name of the city where we live refers to a fruit, Granada [*pomegranate], which, since 1492, has been part of all the coats of arms of Spain). The origin of this choice is unclear and seems to proceed from a folk confusion between Arabic Medina Gar-anat [*pilgrim hill city] and 
the fruit name (<lat. granatum *with grains). This fruit was, in its turn, an ancient symbol of female fertility in Asia and of sexual pleasure in Greece (Chevalier and Gheerbrant, 1969 [2000]: 538).

Though the botanical definition of the term fruit refers to the seed bearing part of a plant, while nut designates the seeds themselves (Blench, 2004: 33), the point is that the "common" meaning of fruto designates more specifically the edible fruits, even including the edible nuts (e.g., sp. frutos secos *dry fruits: "nuts"). The word fruit comes from lat. fructus, from the proto-IndoEuropean root *bhrug "agricultural product" which gave the Latin verb frui/fruor "to enjoy" (Harper, 2014), origin of current words like it. sfruttare "to exploit" $\neq \mathbf{s p}$. disfrutar "to enjoy" [*to take the fruit out]. This analogy between fruit production and other human activities is found in many cultures, as attested by language:

eng. to bear fruit $=\mathbf{s p}$. dar sus frutos $[*$ to give one's fruits] $=$ pt. render frutos [*to return fruits] "to make achievements" = rs. быть плодотворный [*be fruitful] = приносить плоды [*to bring fruits] "to produce good results" = chn. chū chéng guó 出成果 [*achieve fruit] = shuò guǒ léi léi 硕果累累 [*big fruit continuous continuous] "to make many achievements".

eng. the fruit of (one's) labour $=\mathbf{s p}$. el fruto del (/de su) trabajo = fr. le fruit du (/de son) travail $=$ it. il fruto del (suo) lavoro $=\mathbf{g r m}$. die Früchte ihrer Arbeit = rs. плод (своего) труда $=$ chn. gōng zuò chéng guǒ 工作成果 [*work fruit+harvested] "the result of effort" (http://baike.baidu.com).

eng. $=$ not to be the fruit of coincidence $=\mathbf{f r}$. ne pas être le fruit du hasard = it. non essere frutto della casualità $=$ pt. não ser fruto da casualidade $\approx$ chn. cheng gōng bù shì ǒu rán, ér shi chi xù de jié guŏ 成功不是偶然, 而是持续的结果 [*success is not a coincidence, but the harvested fruit of persistence] (www.sparta.net.cn).

As an extension, any valuable thing, including money, may be conceptualized as a fruit, as eng. a slice of melon "a percentage of the profits", fruit for the sideboard "easy money" in Australian English (Baker, 1978), br.pt. dinheiro e fruta só servem pra se comer [*money and fruits are just made for eating] (Mota, 1987: 83). In Greco-Roman mythology, economic prosperity was symbolized by the cornucopia, a great horn overflowing with fruits and nuts, replaced by gold coins in modern graphic representations (e.g., the coat of arms of Peru and Colombia or the logotype of the French National
Lottery). The variant $<$ MONEY IS A FRUIT $>$ is also found in many languages:

sp. hacer fructificar su dinero * to make one's money fructify ["invest in productive assets"] $=$ fr. faire fructifier son argent $=$ it. far fruttare $i$ sold $i \neq \mathbf{s p}$. los suegros son como las patatas, sólo dan fruto cuando están bajo tierra [*parents-in-law are like potatoes, they only bring fruit once they are under the earth] (Lloréns Barber, 1987) $\neq$ it. $i$ quattrini rubatti non fanno mai frutto [*stolen pennies never make fruit] "ill-gotten gains seldom prosper" (Guazzotti and Oddera, 2006) $\neq$ chn. yáo qián shù 摇钱树 [*shake money tree], an allusion to the ancient Chinese legend mentioned in the Records of the Three Kingdoms (sān guó zhi 三国志), where coins fell down when shaking the "Money-tree" (yáo qián shù摇钱树) (http://primaltrek.com/moneytree.html).

Since one metaphor leads to another, the unfruitful tree designates UNWORTHY ACTIONS. In Rapa Nui, fruit trees are called rpn. tumu, while fruitless trees have another name, formally not similar, miro, which also means "wood" (Brown, 1982):

eng. unfruitful efforts $=\mathbf{f r}$. efforts infructueux = sp. esfuerzos infructuosos = it. sforzi senza frutto $\approx$ chn. pànduàn shù de hăo huài, yào kàn guǒzi, bùyào kàn yèzi (判断树的好坏, 要看果子, 不要看叶子) [*judge tree part. good bad, must observe fruit, must not observe leave] "to judge a tree, one needs to observe its fruits, not its leaves" z yǔyán zhī bùguò shì yèzi, xíngdòng cái shì guóshi 语言只不过是叶子, 行动才是果实 [*word be only leaf, action only be fruit] "words are just leaves, only the actions are fruits (Yu Wen Xue Xi Wang) $\approx y \bar{\imath}$ duó bù jié guó shi de huā 一朵不结果实的花 [*one CLASSIF. not fructify fruit PART. flower] "a flower that does not become a fruit" "useless effort" (http://www.cet.com.cn). For example, in Xīn hài gé mìng shì ȳ̃ duǒ bù jié guǒ shí de $h u \bar{a}$ (辛亥革命是一朵不结果实的花) *the revolution of Xin Hai is a fruitless flower (www.cet.com.cn/whpd/ls/1434376.shtml). pt. são mais as vozes do que as nozes [*there is more noise than walnuts] "much ado for nothing" = sp. más es el ruido que las nueces $=$ mucho ruido $y$ pocas nueces $\approx$ amor irresoluto, mucha flor y poco fruto [*undecided love, many flowers and scarce fruits] $\approx$ it. molti pampani e poca uva [*many 
vine leaves but few grapes] $\approx$ essere quattro noci in un sacco [*to be four walnuts in a sack] zla pianta che ha molti frutti non le matura tutti $=$ gli alberi grandi fanno più ombra che frutto $\approx$ albero spesso trapiantato, mai di frutti $\dot{e}$ caricato [*tree often transplanted is never loaded with fruit] $($ Guazzotti and Oddera, 2006) $=$ eng. great trees give more shade than fruit $\approx \mathbf{f r}$. arbre trop ramé fait à peine riche fruit [*tree with too many branches does not give rich fruits] "great investments may be less productive than little ones";

br.pt. pancada de vara não faz caju ficar maduro [*stick blow does not make cashew become mature] (Mota, 1987: 161) $\approx$ iraq. ar. yahmal et-tamar ila l-Bașra يحمل التمر إلى "*like bringing dates to Bassora] "a useless action" ("to bring coals to Newcastle") (Mahdi Jasim, 2006) = sp. el que lleva a vender manzanas a Algodonales no está en sus cabales [*he who carries apples to sell them in Algodonales is crazy] (Lloréns Barber, 1987); casamiento de amores, no darán fruto esas flores [*marriage for love, these flowers will give no fruit]; asno, mujer $y$ nuez, a golpes dan su fruto [*donkey, woman and walnut give their fruit \{only\} when beaten] (Pascual López, 2012: 287, 328).

More abstract applications derive from the mapping $<$ FRUITS ARE RESULTS>, expressing moral attitudes or values. Semantically, fruits can symbolize GIFTS, thus GENEROSITY, GREED, EGOISM, etc:

sp. mientras tengan frutos los olivos, serán sus amigos los estorninos [*while the olivetrees bear fruits, the starlings will be their friends] (Jurado, 2003) $\approx$ mientras hay cerezas hay pájaros que van a ellas [*while there are cherries, there are birds flying to them] $\approx$ a higuera sin higos no acuden mirlos [*blackbirds do not fly to fruitless fig-trees] $\approx$ acabados los higos, pájaros idos [*figs finished, birds gone] $\approx$ en tiempo de higos no hay amigos [*in the time of figs, there are no friends $] \neq$ mex. sp. acercarse al nopal sólo cuando hay tunas [*to approach the cactus only when there are prickly pears] (Rodríguez Valle, 2005) $\approx$ pt. em tempo de figos nao há amigos [*in the time of figs, there are no friends] (Cascudo, 1970: 146) $\neq$ in tempo dei fichi non si hanno amici $\approx$ quando il villano è sul fico non conosce né parente né amico [*when the villain is on the fig-tree he recognizes neither relatives nor friends] (Guazzotti and Oddera, 2006) $\approx$ neap. quann' 'o mellone jèsce russo ognuno ne vo' ' $n$ a fella [*when the watermelon is red, everybody wants a slice of it] (Zazzera, 2006).

Fruits may also symbolize REWARDS, thus (IN) JUSTICE, as in:

eng. the worst pig often gets the best pear $\approx$ br.pt. o melhor caju é do porco [*the best cashew is for the pig] (Mota, 1987;148) $\approx$ it. ai peggi porci vanno le meglio pere [*the best pears go to the worst pigs] $\approx$ uno ha le voci, altro ha le noce [*someone has the noise, someone else has the walnuts] (Craici, 2001) $\approx$ sp. uno come la fruta aceda, y otro tiene la dentera [*someone eats the bitter fruit and someone else has his teeth on edge] $\approx$ pt. uns comem os figos e a outros rebenta-lhes a boca [*some people eat the figs and other people's mouths explode] (Pamies, 2014);

fr. on ne jette des pierres qu'à l'arbre chargé de fruits $\left[{ }^{*}\right.$ we throw stones only at the tree loaded with fruits] $\approx$ tk. meyve-li ăgacl taşlarlar [*the tree bearing fruits get stones] (Divitçioğlu, 2011: 130) $\approx$ pt. br. cajueiro doce é quem leva pedrada [*the sweet cashew-tree is the one we throw stones at $] \approx$ em árvore sem fruto não se atira pedra [*nobody throws stones at the fruitless trees] (Mota, 1987: 62, 88) $\approx \mathbf{s p}$. peralito te tiran piedras porque tienes peras [*small-pear-tree, they throw stones at you because you have pears] (Lloréns Barber, 1987).

Grammatically, these metaphoric idioms show until what point the semantic roles governing constructional patterns depend on the underlying image (Dobrovol'skij, 2011; 2014). The semantic frame GIFT presupposes an Agent (the "giver"), a Patient (the "gift") and a Beneficiary (the "receiver"), and "give" has the lexical function [Oper.]: eng. to give fruits $=\mathbf{s p} . / \mathbf{p t}$. dar frutos $=$ it. dare dei frutti "to be fruitful", as a light verb with consequences on the lexical and syntactic variation. Once this pattern is codified into language, other components may replace the word give. In fruit idioms on EGOISM like sp. a higuera sin higos no acuden mirlos [*blackbirds do not fly to fruitless fig-trees] /acercarse al nopal sólo cuando hay tunas [*to approach the cactus only when there are prickly pears], trees are the "givers", fruits are the "gifts" and the implicit "receivers" are "selfish people". In fruit idioms on INJUSTICE, we can observe the symmetry between give and receive, as a "conversive pair" (Dobrovol'skij, 2011; 2014), focusing on the fact that a reward was not given to the deserving beneficiary, no matter if the verbs give/receive are explicit 
or not. E.g., eng. the worst pig often gets the best pear = pt.o melhor caju é do porco [*the best cashew is for the pig] = it. ai peggi porci vanno le meglio pere [*the best pears go to the worst pigs] $\approx$ fr. on ne jette des pierres qu'à l'arbre chargé de fruits [* we throw stones only at the tree loaded with fruits], etc.

The valences and the allowed ellipsis depend on semantic roles imposed by the metaphoric model itself. This explains why the grammatical restrictions are not the same in the model <FRUITS ARE MONEY>: The Addressee's slot does not need to be fulfilled because the money Possessor's mark refers to the same person (sp. hacer fructificar su dinero *to make one's money fructify), or because it is considered by default as the same person as the Agent (chn. yáo qián shù 摇钱树 *shake money tree). If the roles can switch within the semantic frame, the syntactic restrictions may also change, as in it. essere una pigna verde [*to be an unripe pine-cone] "to be greedy" (Craici, 2001). Here a fruit is the attribute in a structure with no Action, thus no Agent-Patient-Addressee relations; according to the "image", greedy persons keep their money like unripe cones retain their only edible part (seeds), thus, actancy roles have also undergone grammatical metaphors.

In our examples for the model <FRUITS ARE RESULTS $>$, an important degree of variation is possible, depending more on the semantic images than on the literal component give, whose place can be occupied by a synonym or by any other realization of the same archimetaphor: eng. to bear fruits; pt. render frutos [*to return fruits] or rs. приносить плоды [*to bring fruits].

These facts confirm Dobrovol'skij's views on the interrelationships between Construction Grammar and Phraseology. This author has investigated productive and symmetric variations in bi-valential idioms from several semantic fields and found abundant examples of diathesis inversions: rs. дать в лоб (*to give on the forehead: "to beat [someone]") vs. получить в лоб (*to receive in the forehead: "to be beaten") (2011: 209-210); grm. eins auf die Nase geben (*to give one on the nose: "to beat [someone]") $\neq$ eins auf die Nase bekommen (*to get one on the nose: "to be beaten") (2014). Sometimes, the direct object of "give/receive" is itself an idiom, as in rs. дать/получить зеленый свет eng. to give/receive the green light (2011: 225), so the whole phrase forms a collocation. The same applies in Spanish for dar/recibir luz verde. According to the rule of recursive imbrication of phrasemes, a collocation may include an idiom, or even another collocation, as in the same way a nominal phrase can include another one (Pamies, 2013). This type of "phraseological conversives" opposes causative, decausative and re-causative variants, in a productive and systematic way (though restricted to a reduced paradigm), especially by means of aspectual morphemes in the case of Slavic languages. E.g. rs. сидеть на хлебе и воде * to be sitting on bread and water [+LOCATIVE] "to live from hand to mouth") $\neq$ посадить на хлеб ив оду * to sit \{someone\} on bread and water [+ACCUSATIVE] "to punish by deprivation"). This diathetic opposition is very similar in Spanish, by means of lexical variation: estar a pan y agua (*to be at bread and water) $\neq$ poner a pan y agua (*to put at bread and water). The global meaning may sometimes become very different. E.g., rs. стоять на ушах (*to be standing on the ears "to party down") $\neq$ встать на уши (*to rise on the ears "to get nervous") $\neq$ поставить на уши( on the ears "to give a thick ear") (Op.cit.: 209-210).

We find also "conversive pairs" in our corpus, such as dar frutos (*give fruits) vs. recibirlos frutos de... (*receive the fruits of...). There is also a passive variant with "harvest" (recoger los frutos de...), but external to this formal micro-paradigm and motivated directly by the semantic model <FRUITS ARE RESULTS>, while the "receive" metaphor (recibir los frutos) is only an indirect variant derived from the "give" metaphor.

Nevertheless, the symmetry between the "active" and "passive" variants is not straightforward, also for semantic reasons, since both poles include different grammatical metaphors. In dar fruto, an original Action becomes the figurative Agent of "giving", its Consequences become a fruit and its real Beneficiary is normally implicit (su investigación no dio fruto [*his research gave no fruit]). By contrast, in recibir los frutos, the real Beneficiary becomes the figurative Agent of "receiving" (thus it must be explicit), while the real Agent of an original action becomes a figurative Prepostional phrase which depends on the fruit: quien persevera recibirá el fruto de su trabajo [*those who persevere will receive the fruit of their work]. Phrasemes always involve grammatical metaphors besides their semantic metaphors (Pamies, 2013) and these idiomatic variants are not regular enough to be constructions, but too productive to be frozen expressions in the traditional sense of phraseological fixedness (Dobrovol'skij, 2014).

\section{Interaction with Cultural Analogies}

Many idioms and proverbs are motivated by the archi-metaphor $<$ FRUITS ARE RESULTS $>$; however, in the Christian world, this model is mixed with religious culturemes. In spite of the obvious conceptual analogy motivating this semiotic transfer, we must take into

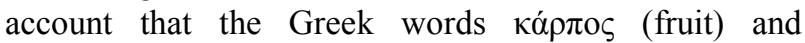
карлофо́ро [*bringing fruit] designate in the Gospels the consequences of physical and spiritual acts, while

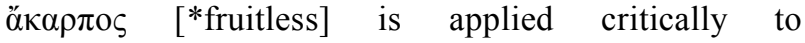
"unproductive actions" (Matthew 3: 10; 7: 19;13: 22; Luke 8: 15), conceived as "useless trees": Every tree that bringeth not forth good fruit is hewn down and

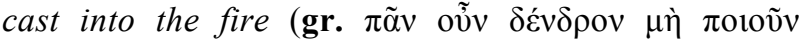




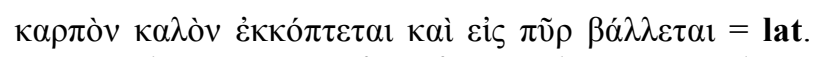
omnis arbor, qua non facit fructum bonum, excidetur, et in ignem mittetur) (Matthew 7: 19; cf. also Mare, 2014), an idea shared by proverbs like:

\begin{abstract}
sp. árbol que no frutea, bueno es para leña [*fruitless tree is good for firewood] $\approx$ árbol que fruto no da, solo es bueno para el llorar [*fruitless trees are good only for crying] $=$ it. albero che non fa frutto, taglia taglia [*tree making no fruit, cut, cut] $=$ sic. árvulu ch'un $f a$ fruttu taglialu di piedi [*tree making no fruit, cut it right down] (Alaimo, 2006).
\end{abstract}

The distinction between GOOD and EVIL people is also the target of the fruit/result archi-metaphor: People must be judged by their deeds, as the trees are judged by their fruits, according to an ancient Greek proverb:

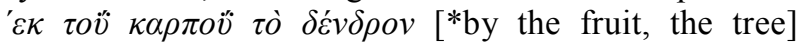
(Pascual López, 2012: 142). In European culture, this image is melded with religious beliefs, since the Gospels said lat. ex fructu cognoscitu arvor (Luke 6: 43-45), an image inherited by many European folk proverbs:

eng. a tree is known by its fruit $=$ grm. an den Früchten erkennt man den Baum = an ihren Früchten sollt ihr sie erkennen $=$ rs. 0 дереве судят по плодам, о человеке -по его делам= fr. c'est au fruit qu'on connaît l'arbre = on connaît l'arbre à ses fruits = it. dal frutto si conosce l'albero $=\mathbf{r m n}$. copacul după fruct se cunoaşte = pomul din rodul lui se cunoaste, de e bun sau de e rãu = pt. pelo fruto se conhece a árvore $=\mathbf{s p}$. por el fruto se conoce el árbol = por sus frutos los conoceréis $\approx$ ni de la zarza buen manzano ni de mal mozo buen cristiano [*no good apple from a bramble bush, no good Christian from an evil youngster].

Another model mixing the FRUIT/RESULT archimetaphor and religion motivates the Spanish sayings si de nogal no dio nueces, de santo ¿qué te parece? [*if he didn't give walnuts when he was a walnut-tree, what do you think he will he do as a Saint?] $\approx$ si de peral no diste peras, ¿qué milagro de ti se espera? [*if you gave no pears as a pear-tree, what miracle can be expected from you?] (Lloréns Barber, 1987), both meaning "if someone did not help you when he was a poor devil, don't expect anything from him once he becomes powerful", referring implicitly to the kind of wood the Saint's statue is made of.

Western literature is also a source of culturemes related with fruits and results, such as Aesop's famous

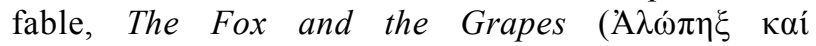
$\sigma \tau \alpha \varphi v \lambda \eta$ ), adapted into Latin by Phaedrus), which even generated an idiom meaning “to conceal one's frustrated desires or expectations":

eng. like the fox and the grapes = fr. comme le renard avec les raisins $=\mathbf{s p}$. como la zorra con las uvas = it. come la volpe con l'uva $\approx$ la volpe che non arriva all'uva dice che $e^{\text {' }}$ acerba $[*$ the fox that cannot catch the grapes says they are sour] $\approx$ pt. essas uvas são verdes [*these grapes are unripe].

The anticipation of the desired result gives rise to variants where fruits symbolize EXPECTATIONS. In this case, the generic fruit is often replaced by more concrete hyponyms, which differ inter-linguistically according to climate and local gastronomic preferences, as in proverbs meaning "we must make sacrifices now in order to get some goods in the future".

eng. he that will eat the fruit must climb the tree $=$ he that will eat the kernel must crack the $n u t=$ fr. pour manger la noix il faut casser la coque [*to eat the walnut, one must crack the shell] $=$ il faut casser le noyau pour en avoir l'amande [*one must crack the shell in order to get its almond] $=$ au fond $d u$ taillis sont les mûres [*blackberries are deep inside the bramble bush] = pt. quem quer bolota sobe à carvalha [*he who want acorns must climb up the oak] (Pamies, 2014) = maur. ar. alli mā rGa-ha xadra mā yawkal-ha tamra [*those who don't take care of their unripe palm-tree will not eat its dates] (Ould Mohamed-Baba, 2008: 164) $\approx$ quien guarda la higuera guardará su fruto $\approx$ quien quiera higos de Lepe, que trepe (Lloréns Barber, $1987) \approx$ it. chi vuol mangiar frutto non colga tutti $i$ fiori [*he who wants to eat fruit must not pick all the flowers] (Quartu, 1993) $\approx l e$ radice della virtù sono amare ma il frutto è dolce [*the roots of virtue are bitter but the fruit is sweet] (Guazzotti and Oddera, 2006) $\approx$ lat.amare iuueni fructus est, crimen seni [*to love is a fruit for youth, but a crime for old people] $=\mathbf{s p}$. el amor es fruta para el mancebo, para el anciano veneno (Pascual López, 2012: 269,728).

The anticipation of RESULTS also affects fruit images in proverbs criticizing over-optimistic attitudes, either in the "temporal" sense, like sp. no me digas 'oliva'hasta que no me veas cogida [*don't call me 'olive' until you see I'm caught] (Jurado, 2003), or in the "qualitative" sense, like eng. plant the crab-tree where you will, it will never bear pippins $\approx$ br.pt. castanha assada nao é dendê 
[*grilled chestnut is not palm oil] (Mota, 1987: 65) $\approx$ chn. zhòng guā dé guā, zhòng dòu dé dòu 种瓜得瓜, 种豆得豆 [*plant melon get melon, plant bean get bean] "as you sow, so shall you reap". A derogatory variant is br.pt. pensar que maracuja é marmelo [*to believe that passion fruit is quince] (Mota, 1987:165). Though the empirical basis of these cognitive metaphors is evident, it is also mediated by religion, because Jesus Christ himself said that men do not gather figs from thorns, nor do they gather grapes from a bramble bush (Luke 6: 44) (cf. also Matthew 7: 16), an image motivating further proverbs like:

grm. Disteln tragen keine Trauben [*wild thistles do not bring grapes] $\approx$ Man liest nicht Feigen vom Dornstrauch [*we can't get figs from a thorn-bush] $\approx$ fr. il ne vient pas de prunes d'un chardon [*plums do not come from thistles] $\approx$ it. il pruno non fa melarancie [*the plum-tree does not make sweet oranges] $\approx$ il leccio non fa olive [*the oak does not make olives] $\approx$ pl. wierzba gruszek nie rodzi [*the willow does not generate pears] (Strauss, 1994) $\approx$ kurd. drrk trê nagrê [*thistle does not bear grapes] (Muhsin Ismail, 2011: 169) $\approx$ sp. no hay que pedir peras al olmo [*don't expect pears from the elm-tree] $\approx$ al pie del helecho no busques el dátil [*don't look for dates under a fern-tree] $\approx$ no pidáis cerezas al cardo [*don't expect cherries from the thistle] $\approx$ el roble no puede llevar camuesas $[*$ the oak cannot bear pippins] $\approx$ pedir uvas al pepino es desatino [*to expect grapes from a cucumber is a silly thing] (Lloréns Barber, 1987) $\approx$ mex.sp. no le busques tunas a los huizaches [*don't look for prickly pears under a huizache]. Huizache is a Nahuatl word designating different trees with no edible fruit and full of big thorns (<nht. huixachi < huitzli "thorn" + ixachi "many") (Rodríguez Valle, 2005).

Nevertheless, not all cultures are equally obsessed by productivity. We find an almost opposite attitude in this Tongan proverb: tng. hoha'a he kuo holo ha fu'u mei [*don't worry while no breadfruit has fallen from the tree] "we must not worry about things which have not happened yet" (Māhina, 2004: 130).

\section{The Metaphoric Model Fruits are Offspring}

\section{Conceptual mappings}

This archi-metaphor is a conceptual analogy between human and botanical reproduction: eng. the apple doesn't fall far from the tree = lat. non procul a proprio stipite poma cadunt [*] (Pascual López, 2012:) ₹ grm. der Apfel fällt nicht weil vom Stamm $=$ rmn. mărul nu cade de parte de pom (Flonta, 2001) = rs. яблоко от яблонки недалеко падаёт $=$ it. la mela non cade lontano dall'albero $=\mathbf{f r}$. le fruit ne tombe jamais loin de l'arbre $\approx \mathbf{j p}$. kino-mi wa moto-he otsuru 木の実は本へ落つ (Paczolay, 1997] [*the fruit falls near the base $] \approx$ chn. guā dié mián mián瓜追绵绵 [*melon small incessant incessant] "I wish you numerous offspring" $\approx$ shén me shù kāi shén me huā, shén me zhǒngzǐ jié shén me guā 什么树开什么花, 什么种子结什么瓜 [*so is tree so is flower; so is seed so is melon] "people resemble those who have educated them" (Xu and Ying, 2011).

This model also motivates international proverbs meaning "offspring are very similar to their parents":

lat. a radice mala non procedut bona mala [*from a bad root comes no good apple] (Pascual López, 2012: 419) $\approx$ eng. as the tree so the fruit $\approx \mathbf{f r}$. tel arbre tel fruit $\approx$ de doux arbre douces pommes [*from sweet tree sweet apples] $\approx \mathbf{s p}$. de buen árbol buen fruto $=\mathbf{p t}$. de boa árvore bom fruto [*from good tree good fruit] $\approx$ sp. nunca buen fruto de mal árbol [*badtree does not give good fruit] = pt. árvore ruim não da bom fruto $\approx$ de tal acha tal racha, de tal árvore tal fruto [*from such $\log$ such crack, from such tree such fruit]

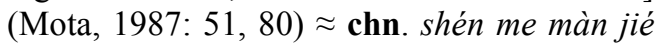
shén me guā 什么蔓结什么瓜 [*such vines produce such melons] (Dian, 2015).

In French and Portuguese, there is even a complete synonymy between tel arbre tel fruit /de tal árvore tal fruto \& tel père tel fils /tal pai tal filho, where FRUIT and SON, or FATHER and TREE, are mutually commutable.

We can observe that the analogy motivating the model <FRUITS ARE OFFSPRING> compares two states (finished product and its origin), while the model FRUITS ARE RESULTS refers to a process (growing, ripening, harvesting). This semantic difference is practically enough to explain the rethoric and syntactic differences between the expressions of both groups.

\section{Interaction with Cultural Analogies}

Culture is partially involved in this conceptual mapping, since the Bible commands: be fruitful and increase in number (Genesis, 1: 28; cf. also Mare, 2014). The Ave Maria prayer says blessed art thou among 
women and blessed is the fruit of thy womb (Luke, 1: 42), using a metaphor that was already in the Old Testament (Cf. Genesis, 30: 2; Deuteronomy, 7: 13; 28: 53; 30: 9); Psalms 127: 3; Isaiah 13: 18): eng. the fruit of thy $w o m b=\mathbf{s p}$. el fruto de tu vientre $=\mathbf{g r m}$. die Frucht deines Leibes $=$ rs. плод чрева твоего. Another convergence between "biological" analogies and religion motivates this Palestinian Arabic proverb: leš-

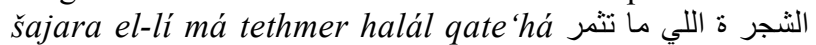
[*the tree which gives no fruit must be cut] meaning "the wife who brings no children must be repudiated" (Al-Sharab, 2010: 308).

Racial preconceptions may also affect the association between fruits and offspring. The Brazilian word jenipapo is the folk name of the Genipa Americana, a fruit used for corporal painting by the Indians (<Tupi yandi 'pawa" *fruit for painting). By metonymy, this word also means "birthmark", extended to racial impurity, so the idiom ter jenipapo nas cadeiras [*to have jenipapo in the hips] means "to be a mulatto girl" (Mota, 1987: 219).

\section{The Metaphoric Model Fruits are Moments}

\section{Conceptual Mappings}

In peasant cultures, the crop of the fruits was a way of measuring time: Spring is called le temps des cerises [*the time of cherries] in French and wàng xìng 望杏 [*look at peach] in Chinese, while February is called xìng yuè 杏月 [*apricot moon], March is táo yuè 桃月 [*peach moon], and méi yǔ 梅雨 [*plum rain] designates a period of intermittent rains between June and July in Lower Changjiang region. In Sinaugoro, foia (a type of nut) designates also the whole period of nut falling (December-January). In Brazilian Portuguese, chuva de caju [*cashew rain] designates the rainy period which coincides with cashew ripening (Mota, 1987: 238), while caju [*cashew] means also "year" in the idiom br. pt. quántos cajus? [*how many cashews?] "how old are you?". The euphemism eng. mature, used to designate elder people, is also derived from this botanic analogy (sp. la madurez [*maturity] $\approx$ fr. l'âge mûr [*the ripe age]), as well as the dysphemistic br.pt. velho é bananeira que ja deu cacho [*oldman is banana-tree which already gave bunch] $\approx$ velho é jerimum na ponta da rama [*oldman is pumpkin on the branch tip] (Mota, 1987: 227).

The time of ripening is a figurative point of reference for many other things:

lat. pira dum sunt matura sponte cadunt [*when pears are ripe they fall by themselves] "there is a moment for everything" = sp. cuando las peras maduran, en el árbol poco duran [*when pears ripen they do not last on the tree] (Cantera Ruiz de Urbina, 2005) $\approx a$ su tiempo maduran las uvas [*in their time grapes ripen] $\approx$ no cojas la pera hasta que esté madura [*dont pick the pear until it is ripe] (Sevilla Muñoz, 2008-2011) $\approx$ grm. wenn di Frucht reif ist, fällt sie von selbst $a b$ $\approx$ Wenn der Apfel reif ist, fällt er $a b \approx$ man kann die Birne nicht eher pflücken, bis sie reif ist [ ${ }^{*}$ one must not pick the pear before it is ripe] $\approx$ it. quando la pera è matura casca da $s e ́ \approx$ non ci sono dei frutti si duri che il tempo non maturi fr. il n'y a de fruit si dur et acerbe qui ne mûrisse [*no fruit is so hard that time cannot ripen it] $\approx$ it. col tempo e con la paglia maturano le nespole (Durante, 2010) $\approx \mathbf{f r}$. avec la paille et le temps, se mûrissent les nèfles et les glands [*with straw and time, loquats and acorns ripen] $\neq$ laisser mûrir la poire [*let the pear ripen] "wait for the adequate moment" $\neq$ br.pt. jerimum se guarda mas melancia, se não comer logo, apodrece [*pumpkins last but watermelons get rotten -if we don't eat them right now] = mulher deve se casar cedo porque homem é jerimum, mulher é melancia [*Woman must mary soon because man is a pumpkin woman is a watermelon] $\approx$ banana madura não sustenta no cacho [*ripe banana doesn't hang from the bunch] "there is moment for the son to leave his parents' home" (Mota, 1987: 54, $110,125) \approx$ chn. guā er shú le jiù yào zhāi, guǒ zi shú le jiù yào căi 瓜儿熟了就要摘, 果子熟了就要采 $\left[{ }^{*}\right.$ melon mature, soon must pick; fruit ripen, soon must pick] "when a young man is old enough to marry he must do it” $\approx$ guǒ shú dì luò果熟蒂落 [*fruit mature base fall] $\approx$ gān jiāng yǒu zăo, yuè lăo yuè hăo 干姜有束, 越老越好 [*dry ginger dry jujube, older better] "experienced people are wiser" $\neq$ zăo shú de guó zi cháng bù dà 早熟的果子长不大 [*soon ripe fruit grow not big] "people who learn too fast cannot make great achievements" $\neq j i$ guā ér dài及瓜而代 [*arrive melon CONJ. substitute] "when the melons ripen next year, someone else will take over the job" (Dian, 2015).

\section{Interaction with Cultural Transfers}

In Spain, pears are cropped in August, while grapes are collected at the end of September; consequently, sp. de uvas a peras (*from grapes to pears) means "seldom": taken in this order, almost one year would separate both moments. These "temporal" meanings may be understandable only in certain regions for climatic and/or gastronomic reasons. Though figs have several crops everywhere, few languages have different names to 
distinguish them, so sp. de higos a brevas [*from figs to breba figs] also means "seldom", since (main crop) figs are picked at the end of summer, while breba figs (first crop from the same tree) are picked in June, thus, almost one year later if taken in this order. In Brazil, the word caju [*cashew] designates the (real) fruit, a pear-shaped mesocarp, whose juice is appreciated. The cashew juice is called cajuina and is also distillated as a liquor called caium. Before the Portuguese conquest, the Tremembé indigenous already produced a fermented drink called mocororó "brew of cashew", while its big external seed is called castanha de caju [*chestnut of cashew], much more appreciated and sold apart. Since, in other countries, only the nut is eaten, cashew is identified only with the seed (fr. cajou, grm. Kaschu, sp. anacardo). Therefore, the Brazilian phrasemes quando você ia pros cajus, ja eu voltava das castanhas $[*$ when you were going for cashew $<$ fruits $>$ I was coming back from the cashew $<$ nuts $>$ ], quem não come do caju não percebe da castanha [*he who doesn't eat from the cashew $<$ fruit $>$ doesn't understand the cashew <nut>] (Mota, 1987: 174), both referring to the best moment for certain actions, would be a nonsense in cultures where the difference between both kinds of caju is unknown.

A moment very remote in the past may be also evoked by means of fruits: sp. en el tiempo de María Castaña [*in the time of Mary Chestnut] $\approx$ it. quando piovvero fichi e uva passa *when it rained figs and raisins: "Long time ago". By contrast, some biological images which are biologically inconsistent mean "never" ("when pigs will fly"):

gal. cando os carballos dean uvas [*when the oaks will give grapes] $\approx$ cando as maceiras dean peras [*when the apple-trees will give pears] $\approx$ it. quando le querci farano limoni [*when oaks will make lemons] (Lapucci, $1993) \approx$ quando pioveranno uva passita $e$ fichi secchi [*when it will rain raisins and dried figs] (Durante, 2010: 50).

rm. când o face plopul pere si răchita micşunele [*when the poplar will give pears and the willow will give wallflowers] (Ortega Román 2006: 78).

At the beginning of the Perestroika, this idiom was used in a discourse by the former dictator, Nicolae Ceaușescu, who declared, that, in Romania, communism would end only when pears grow on poplar trees. After his fall and execution, in December 1989, in the squares and parks of Timişoara, poplar trees were decorated with pears, to mean that "the prophecy was fulfilled" (http://www.nytimes.com/1989/12/31/weekinreview/theworld-rumania-s-years-of-desperation-days-ofrelief.html).
Comparing these languages, the conceptual metaphor is basically the same, only the fruit species vary. However, religion also interferes in this Iraqi phraseme, ar. māțulbe l-najla tamur, mā ŷuz min šurb el-jamur طuntil dates stop growing on palm-trees I will not stop drinking: "never" (Mahdi Jasim, 2006), since, in the Qoran, dates are a blessed thing while alcohol is forbidden.

\section{Cultural Transfers: Blessed Fruits Vs. Cursed Fruits}

Food is not only a biological requirement, it has also a symbolic dimension, even related to emotions (Mintz, 1996). Fruits are representatives of the ethno-botanic heritage of each nation and, as a basic component of traditional alimentation, they play a role in the construction of the cultural identity of each nation. Many traces of this anthropological background remain in language for centuries. However, their relevance and prestige in gastronomy are irregular: In West and Central Africa they play little role in alimentation while they are fundamental in Amerindian or Polynesian cultures (Blench, 2004: 47). The same fruit variety may remain wild and unappreciated in a given region while considered as a delicacy somewhere else, as it happens among the Pacific Islands (Blench, 2004: 32,). The symbolic importance of each fruit in folk beliefs varies in each culture. In Motu hua means "banana" and the reduplicated plural huahua means "fruit", so this fruit seems a prototype (Lister-Turner and Clark). In Hawaiian mythology, the coconut was a man whose head was planted in the ground, while his penis and testicles dangled above it (Kame'eleihiwa, 1992: 33-34). Thus, cultures may have blessed fruits and cursed fruits and they may be local species which don't exist in other regions.

The tree Rhus taitensis ('âpape in Tahitian, tawai in Hawaiian, tavahi in Tongan), only grows in Oceanic Islands, where it is traditionally appreciated for canoe construction, but to eat its fruit is a type of taboo in Tonga, as reflected by the proverb tgn. fakatu 'atamakiki he'ete taunga 'oku tautau he fu' $u$ tavahi [*misfortune is in the food basket hanging from the tavahi tree]. By contrast, the Indian almonds (Terminalia catappa), telie in Tongan, are associated with good luck: tgn. fakatu 'amelie ki he'ete taunga 'oku tautau he fu'u telie [*fortune is in the sweet food basket hanging from the telie tree] (Māhina, 2004: 101).

Dates have highly positive connotations in Arabic culture. The prophet Muhammad said: لتمر مسامير الركب [*dates are like the nails of the knees] "they bring energy and health" and the Hadid (Sayings of the Prophet) say that eating seven dates for breakfast is a good protection against poison and evil eye, so this fruit is used to celebrate the end of Ramadan (Al-Sharab, 2010: 204241). The Arabic metaphors about dates share these positive connotations: 


\begin{abstract}
Alger.ar. fì hiyāt ištaq tamra ki mā allquh-h 'arŷūn [*when he was alive he wanted a date, now he is dead and he has a lot of them] "success may come too late" (Mekhelef and Monferrer, 1998: 133); Class.ar. ازرع في كل [مان لو حصلت تمرة ما اكلت جمرة date you will not eat jackal] "we must choose the best option"; الخلاص لازم فيه شيص ] [even the dates from Alkhalaas have some bad parts] "no rose without a thorn" (Al-Sharab, 2010; Al-Jallad, 2012).
\end{abstract}

Sometimes the motivation involves in an empirical way some property of the fruit component of an idiom. E.g., we know whether a melon is good only when we have cut a slice of it, sometime too late, thus, some proverbs say:

\begin{abstract}
fr. les hommes sont comme les melons: sur dix il y en a un de bon [*men are like melons, only one out of ten is good] $\approx \mathbf{s p}$. el melón $y$ la mujer, a la cala han de ser [*melons and women, we need to cut a slit] (Lloréns Barber, $1987) \approx$ el casamiento y el melón, por ventura son [*marriage and melon are purely lucky choices] (Sevilla Muñoz, 2008-2011) $\approx$ pt. $d a$ mulher e do melão o melhor é o calado [*from woman and melon the best is the cut slit $] \approx a$ mulher e o melão, ruins são de conhecer [*woman and melon, it's hard to know them] (Mota, 1987: 74, 148) ₹ kurd. gndore be reng nîye [*melon from color is+not] "don't judge a book by the cover" (Muhsin Ismail, 2011: 207).
\end{abstract}

In other cases, cultural symbolism is involved. In French, cherries are connected to misfortune only through language: Avoir la cerise/avoir la guigne [*to have the cherry] "to be dogged by bad luck". This motivation seems opaque, perhaps it refers to the fact that cherries pull each other, getting tangled by their multiple stems, as suggested by a proverb in other Romance languages:

sp. cerezas y males traen detrás otros tales $[*$ cherries and misfortunes bring more of the same] "troubles never come alone" $\approx$ las desgracias, como las cerezas, unas con otras se enredan [*misfortunes are like cherries, they tangle each other] (Lloréns Barber, 1987) $\approx$ las desgracias, como las cerezas, unas con otras se enredan [*misfortunes are like cherries, they tangle each other] (Sevilla Muñoz, 2008-2011) $\approx$ gal. como as cereixas son as desgracias que unhas noutras se engarran [misfortunes are like cherries, they tangle each other] $\approx$ it. le sventure sono come le ciligie: Vengono a due a due [*misfortunes are like cherries they come in twos] (Sevilla

Muñoz, 2008-2011)

In several cultures, the APPLE is a polysemic symbol, merging experience with cultural connotations. It was a sacred fruit for Scandinavian and Celtic civilizations, symbolizing wisdom, female fertility and/or eternal life (Cirlot, 1992). The goddess Iðunn provided the Nordic gods with apples giving them eternal youth (cf. Ellis Davidson, 1965: 165-166). The Svenska Folk Sagor mentions Fountains of youth and priceless apples who could make old people be young again (Washburn Hopkins, 1905: 13-15). The name of the island Avalon, where King Arthur took out Excalibur from the stone, comes from old Welsh aball "apple-tree" (cf. modern Breton aval, modern Welsh afall) (cf. Koch, 2006).

Some of the few traces of this (positive) symbolism in modern languages include the expression apples! meaning "all right" in slang, the proverb an apple a day keeps the doctor away (whose origin, according to Pollan, 2001, is an old marketing slogan for cider in the United States). Admittedly, Lloréns Barber (1987: 154) and Sevilla Muñoz (2008-2011) found equivalents in other languages, but they could be (recent) borrowings from English: sp. no hay cosa más sana que comer en ayunas una manzana $\approx$ una manzana al día, al médico alejaría $\approx$ it. una mela al giorno, toglie al medico di torno $\approx \mathbf{f r}$. pomme du matin éloigne le médecin $\approx \mathbf{r s}$. яблоко в день -доктора в дверь). Anyway, a genuine Spanish comparative collocation says sana como una manzana [*healthy as an apple]. According to Gervasius, Alexander-the-Great was seeking in India the apples that made the Hindu priests live four hundred years (Otia Imperialia: 895 apud. Washburn Hopkins, 1905: 19) and the Persian soldiers who fought against him, the famous ten thousand immortals, were also called the apple bearers (gr. oi $\mu \eta \lambda$ Xenophon (Cyropaedia, VII [1914]).

Greek mythology and Plato's ideas about love (each soul has been split and needs to find its own predestinated beloved half part: Symposium, apud. Pascual López, 2012: 240), gave birth to the HALF A FRUIT metaphor, attested by idioms like eng. the other half of the apple = it. mezza mela $=$ pol. druga połówka jabtka $\approx \mathbf{s p}$. media naranja [*half orange] "soulmate. However, the connotations of the APPLE became ambiguous in Greek culture, because of the mythological Apple of Discord, origin of the Trojan war, that represents -in many languages- the reason of any dispute (sp. manzana de la discordia $=$ fr. pomme de la discorde $=$ grm. Zankapfel = rs. яблоко раздора).

Judeo-Christianism converted the APPLE into a cursed fruit, though, in fact, it was not the forbidden fruit of the Bible. The Vulgata always says "fruit" (fructus), never "apple" (mālum) (Hyeromiana versio: Vulgata, Genesis $3: 1-22$ ), and the same happens in its early translations to modern languages. E.g., But of the fruit of the tree which 
is in the midst of the garden, God hath said, Ye shall not eat of it... (Genesis: 3: 1-22, King James version). The shift seems due to the more frequent use of the word pōmum in liturgy, which meant originally "any fruit with seeds", but - by metonymy - became restricted to apples in the late Empire period, replacing the classical Latin word mālum (cf. fr. pomme; cat. poma "apple"), as did its botanic referent in the cultural symbolism attested by idioms:

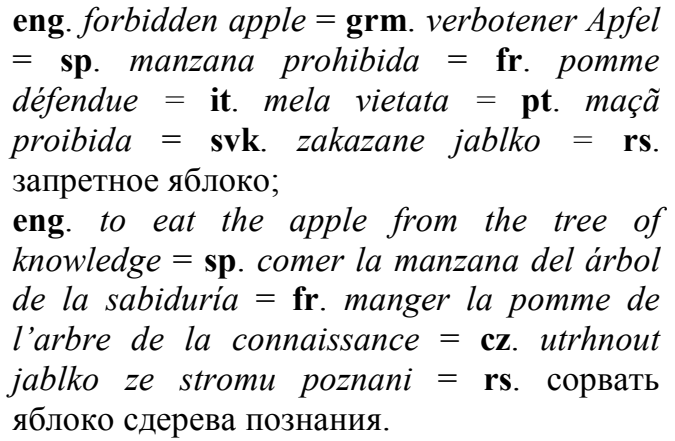

The Collins English Dictionary defines a rotten apple as a person with a corrupting influence (1991-2003). This idiom is derived from a (late) Latin proverb: pomum compunctum cito corrumpit sibi iunctum (Cantera, 2005), meaning "evil spreads from individuals to collectives":

eng. one rotten apple will spoil the whole barrel = one rotten apple decays the bushel = one bad apple spoils the bunch = rs. от одного порченого яблока весь воз загнивает $=\mathbf{g r m}$. ein fauler Apfel steckt den andern an = ein fauler Apfel steckt hundert gesunden an (Strauss, 1994) = rmn. mărul putred strică si pe cele bune (Flonta, 2001) = it. una mela marcia ne guasta cento = la mela bacata rovina le altre $=$ neap. mela vermenosa ne 'nfracita 'nu muntone (Zazzera, 2006) = sp. la manzana podrida pudre a su compañía = la manzana podrida pierde a su vecina $=$ pt. uma maçã podre apodrece um cento $=\mathbf{f r}$. une pomme gâtée en gâte cent $=i l$ suffit d'une pomme pourrie pour gâter le tas. The Judeo-Christian component explains that other fruits replace the apple in other cultures, as in the Turkish proverb üzüm üzüme baka baka kararir [*grapes get darker looking to each other] (Yurtbaşi, 1996). Mutual influence is ambiguosly symbolized, the grapes close together in a bunch get darker: "mature" (positive) or "rotten" (negative), an image which coincides with an ancient Roman proverb, also ambiguous: uva uvam videndo varia fit (Strauss, 1994).
The negative connotations, related to Original Sin, were extended from apples to women:

eng. the fairest apple to the eye may have a rotten core (Strauss, 1994) $\approx$ grm. die Jungfrau siehet roth, doch sitzt ein Wurm darin [*the young woman seems red but there is a worm inside] $\approx$ der schönste Apfel hat oft einen Wurm] [*the nicest apple often has a worm] $\approx$ schöne Äpfel sind wohl auch sauer [*nice apples are often sour] (Wander, 1867) $\approx$ sp. como la manzana, por dentro podrida, por fuera sana [*like the apple, healthy outwardly, rotten inwardly] $\approx$ mujeres $y$ manzanas, muchas hay podridas que parecen sanas [*apples and women, many are rotten who look healthy] (Lloréns Barber, 1987) $\approx$ rmn. merele frumoase pot $f i$ şi viermănoase [*nice apples may contain worms] (Flonta, $2001) \approx$ fr. souvent la plus belle pomme est véreuse $\approx$ it. belli pomi sono anche alle volte amari. Another variant of this mysogynist proverb contains a chestnut instead of an apple, perhaps because of the rhyme: sp. la mujer y la castaña por su apariencia engañan; it. la donna è come la castagna: bella di fuori ma dentro è magagna (Guazzotti and Oddera, 2006) [*nice apples are sometimes bitter].

After the Renaissance, the connotations of the forbidden fruit became less negative. The original religious symbolism began to assume a more hedonistic view. E.g., sp. cojed de vuestra alegre primavera/el dulce fruto antes que el tiempo airado/ cubra de nieve la hermosa cumbre... (Garcilaso, Soneto XXIII) [literally: *pick up the sweet fruit of your merry Spring, before angry Time covers with snow the beautiful peak]). Corneille's verse Plus le péril est grand, plus doux en est le fruit (*the higher the danger, the sweeter the fruit) is an elegant variant of proverbs like:

eng. forbidden fruit tastes the sweetest $=\mathbf{f r}$. les fruits interdits sont les plus doux $=\mathbf{r s .}$ запретный плод сладок = grm. Verbotene Früchte schmecken am besten = verbotene Aepfel sind süss.

In a much less romantic way, some Brazilian idioms also associate the generic fruit with sexuality: br.pt. gostar da fruta (*to like fruits) "to hound women", fruta nova (*new fruit") or fruta verde (*green fruit) "young prostitute" (Cascudo, 1970: 192); moça nova é como o ananas, em cima está verde mas em baixo está capaz [*young woman is like a pineapple: green/unripe above but suitable below] (Mota 1987: 122). The current 
"honorific" nicknames of a special kind of go-go singers at the Carnival are based on fruit names: br.pt. mulher fruta [*fruit woman], mulher melão [*melon woman], mulher melancia [*watermelon woman], mulher moranguinho [*strawberry woman], mulher pêra [*pear woman], mulher mangaba [*hancornia woman] (cf. www.dicionario.sensagent.com $\&$ pt.wikipedia.org). These expressions are supposed to call up some physical similarities (melon for "breast", watermelon for "buttocks", etc.), but they share the cultural association between sexual temptation and fruits. One of these dancers, called mulher maçã [*apple woman] had a great success with the song entitled $A$ maçã, o fruto proibido [*the apple: the forbidden fruit]. In English slang, to lose one's cherry refers to virginity, while a peach is a pretty woman (Ayto and Simpson, 2010).

Another relation between the sexual taboo and a fruit corresponds to BANANAS in Hawaiian culture, where women are not allowed to eat them in the presence of men (Kame'eleihiwa, 1992). By contrast, in Māori culture, the SWEET-POTATO (kumara) has the connotations of a desired object, as in this proverb on modesty: kaure te kumarae wheakii ana tana teka [*the sweet-potato does not say how sweet she is] (Fletcher, 1922).

In China, the PEAR (chn. lí 梨) must not be given as a present because of its homonymy with $l i$ 离 ("to split"), while "to cut a pear" (fên li分梨), whose pronunciation is also the same as $l i$ 分离 ("to separate), is considered a BAD OMEN. By contrast, in Latin culture, the PEAR and the CHERRY have positive connotations, as attested by idioms and proverbs like sp. ser una perita en dulce [*to be a small pear in sugar] "to be very appetizing" $\neq$ ser la pera [*to be the pear] "to be amazing" $\approx$ partir peras [*to share pears] "to have fair relations with someone" $\approx$ pt. jogar as peras [*to play one's pears] $\neq \mathbf{s p}$. con mayor que tú no partas peras [*don't share pears with someone bigger than you] = de ninguna manera con tu amo partas peras $\left[{ }^{*}\right.$ never share pears with your master] $=\mathbf{p t}$. com teu amo nao jogues as peras [*don't play your pears with your master] (Mota, 1987: 72; Ribeiro, 1984: 78) $\approx$ lat. cum domino cerasum res est mala mandere seruum [*the servant eating cherries with his master is something wrong] = sp. si comes cerezas con tu señor, tú las comerás de una en una y él dos a dos [*if you eat cherries with your lord, you will eat them one by one and he will eat them in twos] (Pascual López, 2012: 522523). The motivation of this image is more transparent in the French proverb qui avec son seigneur mange poires, il ne choisit pas les meilleures [*he who eats pears with his lord cannot choose the best ones] (Sevilla Muñoz, 2008-2011), origin of the current idiom fr. couper la poire en deux [*to divide the pear in two] "to share all risks and benefits with someone".
The DATES are blessed for Muslims, whose Heaven is full of them, but, because of that, the Kurdish idiom ç $\hat{u}$ bo xurma xuardn [*he's gone to eat dates] is a euphemism for "he's dead" (Muhsin Ismail, 2011: 174).

The fruits which grow easily are an important element of the traditional diet, but, at the same time, their cheaper price allows them to symbolize (critically) the "lowest value" in figurative idioms and proverbs. This productive archi-metaphor can be described as CHEAP FRUITS ARE CONTEMPTIBLE THINGS. The "chosen" fruits change in each culture but the metaphoric pattern is the same. In English and Italian, the FIG corresponds semiotically to the PLUM in French, the CHILLI PEPPER in Spanish, the BANANA and the SOUR CHERRY in Brazilian Portuguese. This value explains the negative connotations of PUMPKINS in other metaphors, such as sp. dar calabazas [*to give pumpkins] "to be absent in a date" or "to reject a marriage proposal"; más soso que una calabaza [*more insipid than a pumpkin] $\approx$ cuando la mujer manda en casa, el marido es calabaza $\left[{ }^{*}\right.$ when the wife rules the house, the husband is a pumpkin] $\approx$ br.pt.o que dá mais no sertao é menino $e$ jerimum [*the most abundant things in the desert backlands are kids and pumpkins] (Mota, 1987: 152). Depending on its size, one AUBERGINE could be cheaper than a pumpkin, so a Spanish proverb says: nunca de mala berengena se hizo buena calabaza [*from a bad eggplant comes no good pumpkin] (Pascual López, 2012: 863). These fruits are cheap, thus insignificant (Pamies, 2014).

eng. I don't care a fig $\approx$ not to be worth a fig $\approx$ it. non valere un fico secco $\approx$ non importare un fico secco [*not to care a dried fig] $\approx$ tenendo l'ucello non si mangia fico [*if we have got a bird we don't eat a fig] (Guazzotti and Oddera, 2006) $\approx$ fare le nozze con fichi secchi [*to make weddings with dried figs] "to be too thrifty" (Lapucci, 1993); fr. ne pas valoir une prune [*not to be worth a plum] "to have no value" $\approx$ ne pas donner une prune (pour quelqu'un) [*not to give a plum (for smb.)] $\approx$ donner une prune pour deux oeufs [*to give a plum for two eggs] "to make a good business" $\approx$ aimer mieux deux oeufs qu'une prune [*to prefer two eggs to a plum] "to be smart" $\approx$ faire cent sauts pour une prune [*to jump a hundred times for a plum] = travailler pour des prunes [*to work for plums] "to work in vain" $\approx$ compter pour des prunes [*to count for plums] "to count for nothing" $\approx$ des prunes! [*plums!] "no way!" $\approx$ mangez de nos prunes: nos pourceaux n'en veulent plus [*eat our plums: our pigs don't want them] (Pamies, 2011); 
sp. no valer un pimiento [ ${ }^{*}$ not to be worth a chilli pepper] $\approx$ no dar un pimiento (por alguien/algo) [*not to give a chilli pepper (for smb.)] $\approx$ importar un pimiento [*to care a chilli pepper] $\approx i y$ un pimiento! [*and a chilli pepper!] "no way!" $\approx$ vale más un pimiento regalado que todo el huerto rogado [*a given chilli pepper is better than the whole field implored] $\approx$ del avariento, ni un pimiento [*from a greedy man, not a single chilli pepper] (Pamies, 2011);

br. pt. a preço de banana [*at banana's price] "very cheap" $\approx$ república das bananas [*banana republic] "corrupted and ineffective country" $\approx$ dar uma banana [*to give a banana] "to make the finger" $\approx$ levar uma banana [*to bring a banana] "someone made the finger to us" $\approx$ descascar a banana [*to peel the banana] "to masturbate" (Monteiro, 2011) $\approx$ com bananas e bolos se engana os tolos [*bananas and breadrolls cheat the idiots] $\approx$ perguntar se macaco quer banana (*to ask if the monkey wants banana) "asking unnecessary questions" ("is the Pope a Catholic?”) (Mota, 1987: 70, 166) ₹ passar guinja [*to pass sour cherry] "to starve" (Cascudo, 1970). Guinja is a Brazilian variety of Prunus cerasus, whose bad taste make it "poor people's food" (Cascudo: Ibid.).

In Southern China, ORANGES, TANGERINES, "WINTER MELONS" (benincasa hispida) and PERSIMMONS are also very easy to grow, so they have negative figurative meanings if applied to persons. The Cantonese idioms luó ď̌ chéng 箩底橙 [*large+woven+basket bottom orange] and shén tái jú 神台桔 [*altar tangerine] refer, through the image of remaining unsold fruits, to women who still haven't got married. The compound dōng guā 冬瓜 [*winter melon] is a component of derogatory idioms referring to fat women, dōng gua nü 冬瓜女 [*winter melon woman], dà dōng guā 大冬瓜 [*big winter melon]. In Chinese, chī shì zi zhuān jiăn ruăn de $n i \bar{e}$ 吃柿子专拣软的捏 [*to eat persimmon +SUFF. specially choose soft pinch] means "to bully the weak and fear the strong", through the image of persimmon eaters, who choose the softest one on the tree. The ANANAS is a positive symbol in Brazil (br.pt. abacaxi), in the regions where it is produced, an ananas at the entrance of the house indicates that visitors are welcome. It is also called rei dos frutos [*king of the fruits] because the leaves on its top remind one of a crown. However, its connotations are not very positive in the expression pt. descascar o abaxi [*to peel the ananas], which means "to solve a very difficult problem" and, in the state of Pernambuco, the same idiom means "to be a bad dancer" (Alacazum, 2009). Other culturally "cursed" fruits are those used as insults against alleged "poor minded" persons, or as components in idioms related to stupidity. E.g.:

eng. lemon "foolish" = esp. membrillo [*quince] $\approx$ calabacin $\left[{ }^{*}\right.$ zucchini] $\approx$ boniato *sweet potato] cirolón [*big plum] $\approx$ melón [*melon] $\approx$ calabaza [*pumpkin] "idiot" (Luque Durán et al., 1998: 107) ₹ mex. sp. aguacate [*avocado] $\approx$ carib. sp. guanábano] $\approx$ ecuad. sp. mamey [*mammee] (Kany, $1960) \approx$ it. cocomero [*watermelon] $\approx$ essere una testa di cavolo [*to be a cabbage head] "to be stupid") "idiot" $\approx$ fr. vieille noix [*old walnut] $\approx$ tu me prends pour une poire? [*do you take me for a pear?] "do you think I am stupid?" $\approx$ br. pt. banana "idiot" $\approx$ se embananar $\approx$ estar embananado [*to be bananaized] "to be completely confused" (Monteiro, 2011) $\approx$ não sou caju [*I am not a cashew] "I am not so stupid" (Ribeiro, 1984: $64) \approx$ ser um beldroega [*to be a purslane] "to be an idiot" (Cascudo, 1970: 178). In spite of its medicinal properties, Beldroega "purslane" [Portulaca brasiliana)] is very cheap in Brazil, where it grows everywhere [Cascudo, 1970: 178]).

In Cantonese, we can find similar insults: cnt. shǔ tóu shŭ năo 薯头薯脑 [*sweet-potato head sweet potato brain] "stupid and clumsy" $\approx$ zhăng dé xiàng fān shǔ 长得像番薯 [*grow participle like sweet-potato] "with a bulky look" = dà fān shǔ大番薯 * big sweet potato "slow and clumsy". A widely spread proverb also relates stupidity with fruits, though indirectly:

fr. couper l'arbre pour avoir le fruit [*to cut the tree in order to get the fruit] $=$ it. fare come $i$ antichi, che taglavano il fico per cogliere le fiche [*to make like the ancients, who cut the fig-tree to pick up the figs] $\approx$ dare a mangiare le pesche per vendere $i$ noccioli [*to make someone else eat the peaches to sell the pits] $\approx$ rs. срубить дерево, чтобы достать плод [*to cut tree in order to get fruit] $\approx \mathbf{c h n}$. kăn shù chī júzi, bùgù gēnbèn 砍树吃橘子, 不顾根本 [*cut tree eat orange, no care root] "cut the tree to eat the oranges, don't care about the root" (Bai Du Zhi Dao, 2015).

From the syntactic point of view, we can observe that in idioms like eng. not to care a fig; it. non importare un fico secco [*not to care a dried fig], sp. importar un 
pimiento [ $*_{n o t}$ to care a chilli pepper], etc., the constructional pattern also undergoes a grammatical metaphor, in which the FRUIT behaves like a Patient, though these verbs do not normally admit a direct object. This structure would not be possible if these names were used with their literal meaning.

\section{Mapping Reversal}

As already shown in other fields of figurative language (Pamies, 2007; 2008; Pamies et al., 2014), mappings between source and target domains are not uni-directional. Fruits motivate botanic metaphors to designate body parts, but they can also be the target of somatic or zoomorphic metaphors and even of another fruit. These bi-directional models may be "empirical" (associations based on perceptual analogies between the shape of something and a given fruit), like eng. tooth of garlic, or apple of the eye. However, they may also interact with cultural semantic transfers involving folk beliefs (superstitions, mythology, religion), like chn. fó tóu guó 佛头果 [*Buddha head fruit] or eng. Adam's apple.

\section{Body Parts Names $>$ Fruit Names}

The conceptual transfer from human body towards other domains is probably the most extended mechanism in metaphor, even for fruit names:

eng. chestnut $\neq$ tooth of garlic $\neq$ Maltese thumb $=$ Desert thumb (CYNOMORIUM) $\neq$ sp. dátil [*finger] "date" (<lat. dactylus $<$ gr. $\delta \alpha \dot{\kappa} \tau \imath \lambda \mathrm{o \zeta )} \neq$ cabeza de ajo [*garlic head] $\neq$ cipote $\left[{ }^{*}\right.$ penis] $=$ carajo de moro [*Moorish penis] (CYNOMORIUM) $\neq$ chn. $y \bar{a} o$ guǒ腰果 [*waist fruit] "cashew nut" $\neq$ chn. fó shǒu佛手 [*Buddha hand] "fingered citron" (CITRUS MEDICASARCODACTYLUS) $\neq$ fó tóu guó佛头果 [*Buddha head fruit] "sugarapple" (http://baike.baidu.com).

\section{Fruit Names $>$ Body Parts Names}

In spite of the high frequency and universality of somatic metaphors, the human body is also the target domain of many metaphors where FRUIT is the source domain. Proto-Melanesian qiteluk designates at the same time "fruits", "nuts", "nipples" and "testicles" (Blust, 1995), while, in Rapa Nui, hua [*coconut] means also "testicle" (Baker, 1978). In Biliau las [*coconut shell] means also "skull" (Simons and Simons, 1977) while in Sinaugoro, vara [*inner part of the coconut] designates the brain (Tauberschmidt, 1995). In Motu, the verb dobigaga means "to fruit upwards", from dobi "fruit" + gaga "to turn face forwards stretching the neck" (Lister-Turner and Clark, s/d).
Sexual parts are the most usually concerned. The name of the avocado (Persea americana) comes from Spanish aguacate, borrowed from Nahuatl ahuacatl, meaning "testicle", a polysemy which remains in Mexican Spanish aguacate, though reversing the metaphor (Kany, 1960). In Chinese, huáng guā 黄瓜 [*cucumber] means "penis", female breasts are called yìng táo 樱桃 [*cherries] = xiān táo 仙桃 [*immortal peaches] = shuǐ mì táo 水蜜桃 [*peaches] = bái li 白梨 [*white pears] $=m \grave{u}$ guā 木瓜 [*pawpaws], while qié $z i$ 茄子 [*eggplants] designate “fallen tits" and pú táo葡萄 [*grapes] the "nipples". Somatic fruit names are also commonly found in European languages:

eng. apple of the eye $\neq$ gourd $\neq$ melons $\neq$ cucumber $=$ banana $=$ quince $\neq$ acorns $=$ cherries $=$ nuts $=$ walnuts $=$ peanuts $\neq$ austr. eng. table grape "lady's fingers" $\neq$ rhubarb "afterbirth" (Baker, 1978) $\neq$ grm. Augapfel [*eye+apple] $\neq$ Birne [*pear] "head" = Kürbis [*pumpkin] "head" (Mellado Blanco, 2008) \# sp. coco "head"; higo [*fig] "vulva"; úvula [*little grape] "uvula" $\neq$ pómulos [*little apples] "cheekbones" $\neq$ por donde amargan los pepinos [*where cucumbers are bitter] "arse" $\neq$ chil. sp. lúcuma [*eggfruit] "head" = calabaza /zueca [*pumpkin] "head" = tutuma /güira [*calabash] "head" = melón "head" (Oroz, 1949) ₹ cub. sp. papaya [*pawpaw] "vulva" = guayaba [*guava] "vulva" $\neq$ mex.sp. aguacates [*avocados] "testicles" (Kany, 1960) = pt. br. maçã do rosto [*apple of the face] "cheekbones" $\neq$ coco pelado [*peeled coconut] "bald head" $\neq$ banana "penis" $\neq$ Eichel [*acorn] "penis head" $\neq$ fr. pommettes [*little apples] "cheekbones" $\neq$ poire [*pear] "face" $\neq$ citrouille [*pumpkin] "head" $\neq$ fraise [*strawberry] "face" $\neq$ abricot [*apricot] "vulva" $\neq$ gland [*acorn] "penis head"] $\neq$ noix [*walnuts] "testicles" = prunes [*plums] "testicles" $\neq$ it. fica [*fig ["vulva"].

Many of these euphemistic and dysphemistic fruit names function also as idiom components:

eng. nutty as a fruit cake "mad" = to go nuts "to become crazy" $\neq$ to get on (someone's) quince "to exasperate" (from quince as "penis") $\neq$ sp. tocarse la pera [*to touch one's pear] "to masturbate" and "to do nothing" $\neq$ fr. je n'en ai rien à glander! [*I have nothing to acorn] "I don't give a fuck!" $\neq$ qu'est-ce que tu glandes? [*what do you acorn] "what the hell are you doing?" (both from gland 
*acorn as "penis head") $\neq$ se fendre la poire [*to split one's pear] "to roar with laugh" (from poire *pear as "face") $\approx$ motu kiri [*fruit ripening] "to laugh" (Lister-Turner and Clark, s/d).

Christian culturemes may motivate also folk names of non-sexual body parts, such as eng. Adam's apple; fr. pomme d'Adam; gmn. Adams apfel; rs.адамого яблоко; cz. Adamovo ohryzek. A good example of motivation blending is sp. nuez de Adán, where nuez [*walnut] is based on a physical similarity with adult men's glottis, bigger, thus, seen from outside, while Adán is related to a folk belief (a remain of the original sin, still stuck in man's throat). This symbol is absent in Chinese, where this protuberance of man's glottis is called [*throat knot (hóu jié 喉结).

\section{Animal Names $>$ Fruit Names}

Zoomorphism is the second more extended type of metaphoric mapping. Fruit names make no exception to this general rule:

eng. gooseberry (RIBES UVA-CRISPA) $\neq$ snake fruit $($ SALACCA SALACCA) $\neq k i w i \quad(<$ from a Māori word designating a bird) $\neq$ horse mango (MANGIFERA FOETIDA) $\neq$ fr. poiretortue [*turtle-pear] (BURCKELLA FIJIENSIS) (Blench, 2004) \# tun. ar. بيض حمامbith hmem [*dove eggs] (type of OLIVE) \# ناب جمل nab jimal [*camel teeth] (type of OLIVE) لرثمة [*ingar el ragma [*vulture's beak] (type of OLIVE) $\neq$ sp. cornicabra *goathorn [type of OLIVE] $\neq$ picuda [*long-beaked] (Ghalayini and Fendri, 2011) (type of OLIVE) $\neq$ cipote de lobo [*wolf penis] (CYNOMORIUM).

In Motu, $d u d u$ is a shellfish whose polysemic name designates also the "sprout of a fruit after blossom" (Lister-Turner and Clark, s/d). In Chinese, zoomorphic models (including imaginary creatures like Phoenix or the Dragon) are very productive for fruit names, whose symbolism becomes also related to the role of these animals in mythology and superstitions:

chn. shī tóu guó 狮头果 [*lion head fruit] "eggfruit" (LUCUMA NERVOSA) $\neq$ shé pi guó 蛇皮果 [*snake skin fruit] “salak fruit" (SALACCA EDULIS) $\neq$ mi hóu táo 狝猴桃 [*macaque-monkey peach] "kiwi" (ACTINIDIA CHINENSIS $) \neq j \bar{l}$ zhuă li鸡爪梨 [*chicken claw pear] "oriental raisin tree" (HOVENIA DULCIS) $\neq$ $\grave{e} l i$ 鳄梨 [*crocodile pear] “avocado” $\neq$ fèng $l i ́$ 凤梨 [*Phoenix pear] “ananas” $\neq$ hóng lóng guó 红龙果 [*red dragon fruit] (HYLOCEREUS UNDATUS).

\section{Fruit Names $>$ Animal Names}

In previous works on fish names (Pamies, 2010; Pamies et al., 2014) we have quoted several aquatic animals with fruit names, proving the existence of the inverse conceptual mapping between both domains. This archi-metaphor is not necessarily limited to aquatic species: in Australian English apple sauce means "horse" (Baker, 1978). In (Balawaian) Sinaugoro, the word gorava [*mandarin fish] designates metaphorically the "wild chestnut" (Tauberschmidt, 1995: 52) and, in Biliau, wayway dabi [*pit of mango] also designates a sand fish, which eats the mango pits that have been thrown into the sea (Simons and Simons, 1977):

fr. fruits de mer *sea fruits $=$ it. frutti di mare
$=$ pt. frutos do mar = grm. Meerfruchte = rs.
море фруктов "shellfish" / "seafood" $\neq \mathbf{e n g}$.
sea apple = fr. pomme de mer = sp. manzana
de mar = pt. maçã-do-mar (PSEUDOCOLOCHIRUS) $=$ grm. Seeäpfel $\neq \mathbf{e n g}$. lemon shark $=\mathbf{s p}$. tiburón limón $=\mathbf{f r}$. requincitron $=$ grm. Zitronenhai (NEGAPRION BREVIROSTRIS) $\neq$ sp. bellota de mar *sea acorn $=\mathbf{p t}$. glande-do-mar $=$ bolota do mar $=$ rs. морський жёлудь (BALANUS) $\neq$ sp. dátil de $\operatorname{mar}{ }^{*}$ sea date $=$ rs. морскойфиник $=\mathbf{p t}$. mexilhão-tâmara $*$ date-mussel (LITHOPHAGA) $\neq$ fr. tomate de mer $^{*}$ sea tomato $=\mathbf{s p}$. tomate de $m a r=$ it. pomodoro di mare $=$ pt. morango-do-mar *sea strawberry (ACTINIA EQUINA) $\neq$ eng. sea peach $=\mathbf{s p}$. pera de mar *sea pear = patata de mar ${ }^{*}$ sea potato $=$ it. patata di mare (HALOCYNTHIA PAPILLOSA) $\neq$ sp. pez limón *lemon fish (SERIOLA LALANDI) $\neq$ eng. sea cucumber $=$ fr. concombre de mer = sp. pepino de mar = cohombro de mar $=$ pt. pepino-do-mar $=$ it. cetriolo di mare $=$ grm. Seegurke $=$ rs. морские огурцы (HOLOTURIA) (Pamies et al., 2014).

This semantic transfer is also found in Chinese, especially for local sea-shells and fishes: chn. ning méng shā 柠檬鲨 *lemon shark (NEGAPRION QUEENSLANDICUS) $\neq$ hăi guā zĭ氵每瓜子 * ${ }^{*}$ sea + melon seeds (MOERELLA IRIDESCENS) $\neq$ máng guǒ bèi 芒果贝 *mango shellfish (PAPHIA UNDULATA] $\neq$ hăi píng guǒ 海苹果 *sea apple (PSEUDOCOLOCHIRUS); huáng guā $y u$ 黄瓜鱼 *cucumber fish “yellow croaker" (PSEUDOSCIAENA CROCEA). 


\section{Fruit Names $>$ Other Fruit Names}

The degree of saliency of certain features can help a given fruit to be conceptualized by means of another one: e.g. in Italian "tomato" is a *golden apple (pomodoro). In this case the source domain and the target domain are the same (fruits), but it is still a metaphor and not a metonymy, contrary to general assumptions by cognitive semantics (cf. Lakoff and Johnson, 1980: 35, and criticism by Ruiz de Mendoza, 1997).

eng. love apple $=\mathbf{f r}$. pomme d'amour $=\mathbf{i t}$. pomodoro $*$ golden apple $=$ Liebesapfel $*$ love apple = Goldapfel gold apple = "tomato" (SOLANUM LYCOPERSICUM);

eng. sugar apple $=$ custard apple (ANNONA SQUAMOSA);

eng. Malay apple $=$ rose apple $=($ SYZYGIUM $)$;

eng. Indian almond $=$ rs. индийский миндаль $*$ Indian almond $=$ br.pt. amendoada-praia $*$ beach almond $=$ castanhola ${ }^{*}$ small chestnut (TERMINALIA CATAPPA);

eng. grapefruit (<old fr. grappe "bunch of grapes") = pt. laranja-romã *orangepomegranate = laranja melancia *orange watermelon (CITRUS PARADISI);

fr. pomme-de-pin (<pomme *apple + pin *pine-tree) "pine cone" (STROBILUS PINACEAE);

eng. pineapple $(<*$ old. eng. pineapple "pine cone") $=$ esp. piña *pine cone $(<$ old. sp. piña de Indias *Indian cone) $=\mathbf{c h n}$. fèng li 凤梨 [*Phoenix pear], wáng $l i$ 王梨 *king pear (Taiwan) "ananas";

eng. pomegranate (PUNICA GRANATUM) (from medieval Latin pōmum grānātum "apple seeded") = grm. Granatapfel $=$ it. melograno (<class. lat. mālum grānātum);

eng. melon $=$ fr. melon $=$ sp. melón $=$ it. melone (<gr. $\mu \eta \lambda \mathrm{o} \pi \varepsilon \dot{\pi} \omega \mathrm{v}<\mu \eta \lambda_{\mathrm{o}}=*$ apple + $\pi \varepsilon ́ \pi \omega v$ "ripe") (CUCUMIS MELO);

eng. prickly pear $=$ pt. figueira-da-Índia *Indian fig $=\mathbf{f r}$. figue de barbarie *barbary fig $=\mathbf{s p}$. higo chumbo (*chumbo fig) (OPUNCTIA FICUS INDICA), called tuna in Mexico. The barbary fig has no relation with figs at all, it is the fruit of an autochthonous Mexican cactus called nopal (<Nahuatl nohpalli), which became higo chumbo [*lead fig] when imported into Spain);

sp. pepino dulce $(*$ sweet cucumber $)=$ pepino melón $(*$ melon cucumber $)=$ pera melón *pear melon = melón de árbol (SOLANUM MURICATUM); grm. Apfelsine *China apple (CITRUS SINENSIS);

br.pt. castanha de caju *ashew chestnut $=$ rs. инди́йский opéx *Indian nut"cashew" (ANACARDIUM OCCIDENTALE);

it. pomo cotogno $=$ mela cotogna $*$ cotton apple $=$ pt. marmelo $(<\mu \varepsilon \lambda i ́ \mu \eta \lambda$ ov *honey apple) "quince" (CYDONIA OBLONGA) (Etymologically, the English word quince also derives from the "cotton apple" metaphor: lat. cotonéum malum $>$ old fr. cooin $>$ Old English quoyn \& modern fr. coing;

eng. Tahitian chestnut $=$ rs. таитянский opex *tahitian hazelnut (INOCARPUS FAGIFER);

eng. sea mango $=$ fr. faux manguier *false mango $=$ chn. hăi máng guǒ 海芒果 *sea mango (CERBERA MANGHAS); $\neq c i$ li刺梨 $*$ thorn pear $=\mathbf{f r}$. rosier chataîgne $($ ROSA ROXBUNGHII).

chn. mù guā木瓜 *wood melon "pawpaw" (CARICA PAPAYA);

chn. huáng guā黄瓜*yellow melon "cucumber" (CUCUMIS SATIVUS).

sp. melocotón ( $<$ lat. mālum cotonium, *cotton apple) "peach" (PRUNUS PERSICA), while lat. malum persica [*Persian apple] is the etymological root of eng. peach, through old French peske (cf. fr. pêche; it. pesca, pt. pêssego; cat. presec; rmn. piersic);

This phenomenon is so common and systematic that fruit names are not a very reliable evidence for the archeobotanical reconstruction of their origin, or how plants were disseminated along the Pacific Islands, since linguistic forms may easily have been transferred from one fruit to another one (Blench, 2004: 32; 4244). In several Oceanic languages the widely spread lexeme nanas, designating the PINEAPPLE, is in reality a borrowing from Tupi nanás, through Portuguese, merged with the local name of the fruit of the screw palm [PANDANUS] (<proto-Austronesian *pandan, proto-Oceanic padran), a referential switch which would be relatively recent (Ibid.). One of the Philippine names of the bread fruit (ARTOCARPUS ALTILIS) is kamansi, which does not fit with the proto-MalayoPolinesian form $* k u l u(R)$, because it would have been transferred from another fruit of the artocarpus genus, while anona, the Philippine name of the custard apple (ANNONA RETICULATA) would be also merged with ananas by confusion with the pineapple (Op . cit.: 4244). Chinese also includes inter-fruit metaphors:

chn. cì găn lăn 刺橄榄 *thorn olive "bamboo palm fruit” (ARECA CATECHU); shuř bìn láng 


\begin{abstract}
水槟榔) *water olive = yě binn láng 野槟榔
*wild olive (endemic capers: CAPPARIS CHINGIANA] $) \neq y e$ xiāng jiāo 野香蕉 *wild banana (MUSA CHUNII, rare fruit species found only in West Yunnan) $\neq$ yě ping guǒ 野苹果 *wild apple (endemic berries,

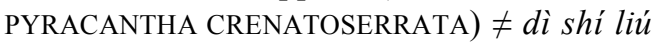
地石榴 *earth pomegranate (FICUS TIKOUA, endemic figlike fruits from Oriental Asia) $\neq$ fān lì zhī 番荔枝 *foreign leechee “sugar apple" (annona squamosa).
\end{abstract}

\section{Culturemes $>$ Fruit Names}

As cultural symbols, imaginary creatures and religious beliefs may also motivate figurative fruit names, as in grm. Paradiesapfel [*Paradise apple] "tomato" (SOLANUM LYCOPERSICUM). Another Chinese name of the sugar apple (ANNONA SQUAMOSA) is fó tóu guǒ (佛头果) [*Buddha head fruit], motivated by its shape, which reminds us of Sakyamuni's head, so it is also called shi jiā guǒ (释迦果) [*Sakyamuni fruit] (http://www. baike. com). Sakyamuni is one of the Buddah's names. Another example is the beautiful tropical fruit HYLOCEREUS UNDATUS, (Fig. 1) called chn. huǒ lóng guǒ火龙果 [*fire dragon fruit], hóng lóng guǒ 红龙果 [*red dragon fruit], qing lóng guǒ 青龙果 [*blue dragon fruit], lóng zhū guó 龙珠果 [*dragon pearl fruit], xiān mì guǒ 仙蜜果 [*immortal honey fruit], yù lóng guǒ 玉龙果 [*jade dragon fruit]. This fruit (Stenocereus) came originally from Latin America, where it is called pitaya, from Haitian Taíno pitahaya (*scaly fruit), (Rodríguez Canto, 2000). Its fragrant flower, which blooms only at night, is called sp. reina de la noche, pt. rainha da noite *queen of the night or $\mathbf{s p . ~ f l o r ~ d e ~ l u n a ~}$ *moonflower).

(baike.baidu.com/view/9288.htm?fr=aladdin, Accessed in April 2015). The dragon is a polysemic symbol with positive connotations in Chinese culture, as a symbol of power, elegance, honor, luck and success. He owns supernatural powers: Moving across skies or seas, controlling the forces of nature on the earth, producing winds and rains and, last but not least, he was the symbol representing the highest ruler, the Emperor who was supposed to have received his power from the Dragon: His title of "Son of Heaven" (zhèn lóng tiān ž̆ 真龙天) was, literally, *real dragon sky son. Nobody but the Emperor could use a dragon as a decorative symbol for his house, carriages and boats, called lóng niăn龙劷 [*dragon carriage], lóng zhōu龙舟 [*dragon boat], etc., to remind other people of his privileges.

The similarity between this fire dragon fruit and the shape and colors of the flames is "blended" with the cultural connotations of the dragon, associating the aristocratic beauty and sophisticated flavor of this expensive fruit to the exclusive privileges of the Emperor (Wang, 1999-2012).

The exotic medicinal fruit SIRAITIA GROSVENORII is called chn. luó hàn guǒ (罗汉果) [*Arhat fruit] and shén xiān guór神仙果 [*immortal fruit] (for Buddhism, arhat or arahant is someone who has reached a deep understanding of the true nature of existence, achieving Nirvāna and, therefore, will not be born again [G.D. Bond 2011 Arhat, http://oxfordindex.oup.com /view/10.1093/obo/9780195393521-0033]) There are several folk versions about the origin of the names of this endemic cucurbitaceae from Southern China (Guilin, Guangxi). According to a legend, there was a pest of insects in the World of Man and Shen Ning -also known as Yandi 炎帝, one of the oldest ancestors of the Chinese People- tried many herb remedies to stop it; so Buddha, compassionate, send him down nineteen Arhat (chn. Luó Hàn 罗汉) to help him. One of them had promised he would not return to Heaven until the pest is eliminated and he was converted into a sanatory fruit which, since then, bears his name (http://zh.wikipedia.org).

The mysterious fruit called chn. rén shēn guǒ 人参果 [*fruit of ginseng] (POTENTILLA ANSERINA) has no botanical relation with the gingseng (root of PANAX), only a cultural one: to produce longevity. According to the legend, the rén shên guŏgives immortality because its shape reminds a baby, its peel has the exact shape of a human body, including head, eyes, ears, nose, mouth, belly button, arms, legs, etc. (Fig. 2).

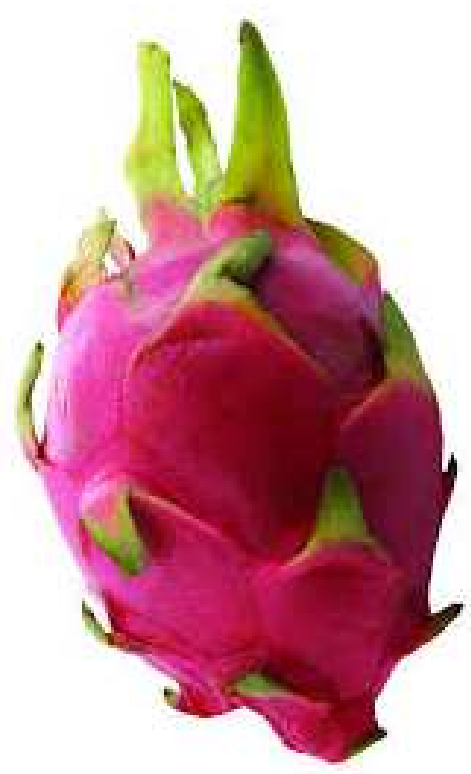

Fig. 1. The "fire dragon fruit" 


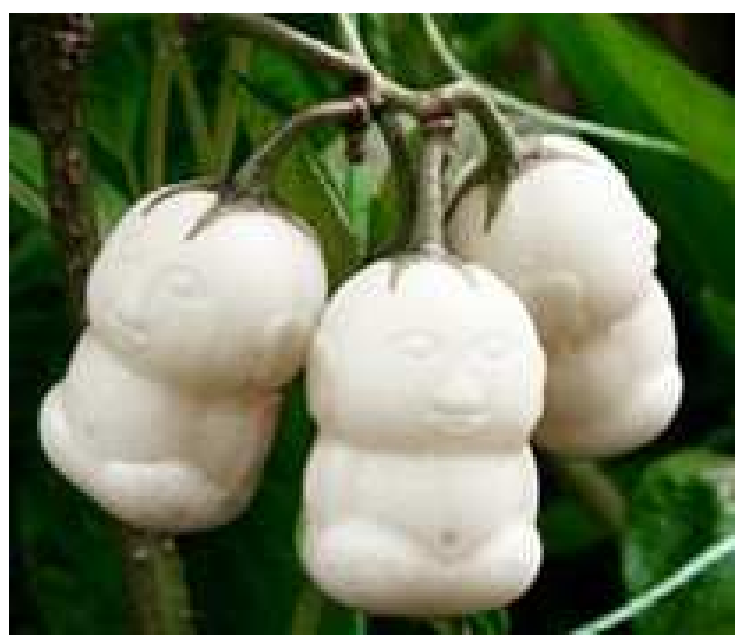

Fig. 2. The "fruit of the gingseng"

In one of the most famous novels of classical literature, $X \bar{\imath}$ yóu ji西游记 (Journey to the West), it is mentioned that this plant grows in the mountain Wàn Shòu 万寿山 [*ten+thousand long-life moutain]. This fruit is also called căo huán dān草还丹[*herb recover Dan] "medicine of Immortality"], because of the belief that this plant blossoms every 3000 years, gives fruits 3000 years later, which ripen after other 3000 years. Therefore, one would need 9000 years to eat it. Besides, during this period, only 30 fruits will be produced. If someone smells it once, he will live 360 years; eating it, one may live 47, 000 years. If the fruit is near gold, it falls down; near wood, it gets dry; near water, it melts; near fire, it burns; if it falls on the ground, it enters the earth (cf. http://baike.baidu.com). This very rare fruit is considered extraordinarily valuable and cannot be bought in any shop, its price in internet is at least 360 yuan (about $45 €$ ) for each piece (http://detail.1688.com).

\section{Conclusion}

In figurative language, fruits may function as a very productive iconic model for archi-metaphors and/or as culturemes, but not only as the source domain, they are also the target domain in many cases. This bidirectionality contradicts some assumptions of the "classical" theory of cognitive metaphor, such as the BODY $>$ MIND rule by Lakoff and Johnson (1980: 118) or the SPACE $>$ TIME rule by Staib (1996: 189), CONCRETE $>$ ABSTRACT (Cuenca and Hilferty, 1999: 103), and it has also been observed in other conceptual domains, such as BIRDS, TREES or FISHES, among others (Pamies, 2007; 2008; 2011; 2014; Pamies and Tutáeva, 2010; Pamies et al., 2014). Fruits are often the target domain for single word metaphors (simple or compound), while they are the source domain in idioms and proverbs.
Experiential and cultural metaphoric macro-models may sometimes interact, blurring their mutual boundaries, which, nevertheless, are relevant, since they oppose the potential universality of archi-metaphors and the ethno-specificity of culturemes.

In spite of the fixedness of phrasemes, idiomatic expressions have a certain degree of variation, which is not completely arbitrary or unpredictable, but rather systematic within the limits of small paradigms. As pointed out by Dobrovol'skij (2011), some groups of variants are regular enough to consider the involved expressions as a micro-paradigm of mutual transformations, instead of independent idioms ("constructional phrasemes"). Within the limits of the archi-metaphor <FRUITS ARE RESULTS>, it is the case of the conversive pairs sp. dar frutos (*give fruits: "produce results") Vs. recibir/recoger los frutos de... (*receive/harvest the fruits of..: "to benefit from the results of..."). The dependence of these syntactic transformations from the underlying semantic image explains that variations allowed for this archi-metaphor cannot function in another one (e.g., fruits are offspring).

\section{Acknowledgment}

The authors aknowledge their informants and colleagues, especially Yara Ghalayini, Rosemeire Monteiro-Plantin, Kamila Tutáeva and Gonzalo Miranda.

\section{Author's Contributions}

Chunyi Lei was responsible for Chinese and Cantonese, Margaret Craig for Oceanic Languages and Australian English, Antonio Pamies, director of the project, was responsible for all the the other languages.

\section{References}

Alacazum, 2009. Alacazum palavras para entreter., 121 (http://alacazum.blogspot.com.es/) (Accessed on January 2015).

Alaimo, E., 2006. Proverbi siciliani. Giunti, Firenze.

Al-Jallad, N., 2012. Diccionario fraseológico-cultural del árabe. Granada Lingvistica, Granada.

Al-Sharab, M., 2010. Estudio lingüístico-cultural del árabe palestino actual. $\mathrm{PhD}$ Thesis, Universidad de Granada, Spain.

Ayto, J. and J. Simpson, 2010. Oxford Dictionary of Modern Slang. 1st Edn., OUP Oxford.

Bai Du Bai Ke 2014 (百度百科) (http://baike.baidu.com/view/9288.htm?fr=aladdin) (Accessed on February 2015).

Bai Du Zhi Dao 2015 (百度知道) (http://zhidao.baidu.com) (Accessed on February 2015). 
Baker, S.J., 1978. The Australian Language. Currawong Press. Pty. Sidney.

Blench, R., 2004. Fruits and Arboriculture in the IndoPacific Region. Indo-Pacific Prehistory Assoc. Bull., 24: 31-50.

Blust, R., 1995. The Austronesian Historical and Comparative Dictionary. Univesity of Hawai at Mānoa, Honolulu.

Brown, C.H., 1982. Growth and development of folk botanical life-forms in polynesian languages. J. Polynesian Society, 91: 213-243.

Cantera Ruiz de Urbina, J., 2005. Refranero latino. Ediciones AKAL, Madrid.

Cascudo, L.D.C., 1970. Locuções tradicionais do Brasil. [reed. 1986] Universidade de São Paulo.

Chevalier, J. and A. Gheerbrant, 1969. Dictionnaire de symboles. Robert Laffont, Paris.

Cirlot, J.E., 1992. Diccionario de símbolos. Siruela, Madrid.

Craici, L., 2001. Dizionario dei modi di dire. Avallardi, Milano.

Cuenca, M.J. and J. Hilferty, 1999. Introducción a la lingüística cognitiva. Editorial Ariel, Barcelona.

Divitçioğlu, E., 2011. Les particularités syntaxiques des proverbes en turc de Turquie. In: Paremiología y Herencia Cultural, Pamies Bertrán, A. and J.D.D. Luque Durán (Eds.), Granada Lingvistica, Granada, pp: 231-242.

Dobrovol'skij, D.O., 1998. On Cultural Component in the Semantic Structure of Idioms. In: Phraseology and Paremiology, Ďurčo, P. (Ed.), Akadémia PZ., Bratislava, pp: 55-61.

Dobrovol'skij, D.O., 2000. La especificidad nacional y cultural en la fraseología. In: Trabajos de lexicografía y fraseología contrastivas, Pamies Bertrán, A. and J.D.D. Luque Durán (Eds.), Método, Granada, pp: 63-77.

Dobrovol'skij, D.O., 2011. Конверсия иактантная деривация во фразеологии. In: Слово и язык: Сборник статей к восьми десятилетию акад. Ю.Д. Апресяна, Boguslavskij, I. (Ed.), Языки славянской культуры, Москва, pp: 207-227.

Dobrovol'skij, D.O., 2014. On the Systematic Variation of German Idioms: Converse Pairs as a Constructional Phenomenon.

Dobrovol'skij, D.O. and E. Piirainen, 2005. Figurative Language: Cross-cultural and Cross-linguistic Perspectives. Elsevier, Amsterdam.

Durante, V., 2010. La noción de tiempo en la fraseología española e italiana. Paremia, 19: 41-51.

Ellis Davidson, H.R., 1965. Gods and Myths of Northern Europe. Penguin, London.

Fletcher, H.J., 1922. A few of the maori wise sayings from lake taupo. J. Polynesian Society, 31: 29-36.
Flonta, T., 2001. A Dictionary of English and Romance Languages Equivalent Proverbs. Hobart, Tasmania. (http: //www: deProverbio. com).

Ghalayini, Y. and M. Fendri, 2011. Léxico y frasemas figurados del aceite y la aceituna en árabe moderno In: Phraseology and Discourse: Cross-Linguistic and Corpus-based Approaches, Pamies, A., J.M. Pazos and L. Luque Nadal (Eds.), Schneider, Baltmannsweiler, pp: 329-336.

Gibbs, R.W., 2007. Psycholinguistic Aspects of Phraseology: American Tradition. In: Phraseologie/Phraseology: Ein Internationales Handbuch der Zeitgenössischen Forschung. Burger, H., D.O. Dobrovol'skij, P. Kühn and N.R. Norrick (Eds.), Mouton de Gruyter, Berlin, pp: 819-836.

Gross, G., 2012. Manuel d'analyse linguistique: approche sémantico-syntaxique du lexique. Presses Universitaires du Septentrion, Villeneuve-d'Ascq.

Guazzotti, P. and M.F. Oddera, 2006. Il grande dizionario dei proverbi italiani. Zanichelli, Bologna.

Harper, D., 2014. Online Etymology Dictionary. (http://etymonline.com/).

Iñesta, E.M. and A. Pamies, 2002. Fraseología y metáfora: aspectos tipológicos y cognitivos. Método Ediciones, Granada.

Jurado, A., 2003. Las voces y refranes del olivo y el aceite. Comunicación Grafica, Madrid.

Kame'eleihiwa, L., 1992. Traditional Hawaiian Metaphors. In: Native Land and Foreign Desires: Pehea LA E Pono Ai? Kame'Eleihiwa, L. (Ed.), Bishop Museum Press, Honolulu, pp: 19-44.

Kany, C.E., 1960. American-spanish euphemisms. University of California Press.

Koch, J.K., 2006. Celtic culture: Aberdeen breviarycelticism. ABC-CLIO, Santa Barbara.

Kunin, A.V., 1996. Курс фразеологии современного английского языка. Высшая школа, Москва.

Lakoff, G. and M. Johnson, 1980. Metaphors We Live By. University of Chicago Press, Chicago.

Lapucci, C., 1993. Il dizionario dei modi di dire della lingua italiana. Avallani, Milano.

Lister-Turner, R. and J. B. Clark, (s/d.: no date). A Dictionary of the Motu Language of Papua. 2nd Edn., A. H. Pettifer, Government Printer, Sydney.

Lloréns Barber, R., 1987. Refranero de los frutos del campo. Taurus, Madrid.

Lóng Nián Huà Lóng: Lóng De Xiàng Zhēng Yì Yì 1999/2012. (龙年话龙: 龙的象征意义), Nóng lì wăng. (www.nongli.com).

Luque Durán, J.D.D., 2007. La codificación de la información lingüístico-cultural en los diccionarios (inter) culturales. In: Interculturalidad y Lenguaje, Luque Durán, J.D.D. and A. Pamies Bertrán (Eds.), Método, Granada, pp: 329-374. 
Luque Durán, J.D.D. and L. Luque Nadal, 2008. Cómo las metáforas recurren a conocimientos ontológicos y culturales. fundamentos teóricos del diccionario intercultural e interlingüístico. In: Phraseologie-Global-Areal-Regional, Korhonen, J., W. Mieder, E. Piirainen and R. Piñel (Eds.). G. Narr, Tübingen.

Luque Durán, J.D.D., A. Pamies and F.J. Manjón, 1998. El Arte del Insulto: Estudio Lexicográfico. Península, Barcelona.

Luque Nadal, L., 2009. Los culturemas: ¿unidades lingüísticas, ideológicas o culturales? Language Design, 11: 93-120.

Mahdi Jasim, R., 2006. El refranero iraquí: aspectos semánticos y socioculturales. $\mathrm{PhD}$ Thesis, Universidad de Granada, Spain.

Māhina, O., 2004. Reed Book of Tongan Proverbs. Reed Books, Auckland.

Mare, W.H., 2014. Fruit. Bible study tools. (http://www.biblestudytools.com)

Mejri, S., 2006. Polylexicalité, monolexicalité et double articulation: La problématique du mot. Cahiers de Lexicologie, 2: 209-221.

Mekhelef, K. and J.P. Monferrer, 1998. Selección de refranes populares argelinos. Paremia, 7: 129-134.

Mellado Blanco, C., 2004. Fraseologismos somáticos del alemán: Un estudio léxico-semántico. Peter Lang, Frankfurt.

Mellado Blanco, C., 2008. La pupila es la "niña": Las metáforas de los lexemas somáticos del alemán y el español. Paremia, 18: 53-63.

Mintz, S.W., 1996. Tasting Food, Tasting Freedom: Excursions Into Eating, Culture and the Past. 1st Edn., Beacon Press, Boston, pp: 149.

Monteiro, R.S., 2011. Gastronomismos fraseológicos: um olhar sobre fraseologia e cultura. In: Uma (re)visão da teoria e da pesquisa fraseológicas, Ortiz Alvarez, M.L. and E. Huelva Unterbäumen (Eds.), Pontes and Universidad Nacional de Brasília, Campinas, pp: 249-276.

Mota, L., 1987. Adagiário brasileiro. Universidade, São Paulo.

Muhsin Ismail, L., 2011. Los refranes kurdos: un estudio lingüístico y cultural del pueblo kurdo. $\mathrm{PhD}$ Thesis, Universidad de Granada, Spain.

Niandou, C., 1997. Organisation structurale et sémantique de la métaphore en Sonay-Zarma. In: La Mémoire des Mots, Clas, A., S. Mejri and T. Baccouche (Eds.), URELF, Tunis, pp: 505-512.

Oroz, R., 1949. Metáforas relativas a las partes del cuerpo humano en la lengua popular chilena. Thesaurus, 5/1-2-3-: 85-100.

Ortega Román, J.J. 2006. Paremiología y fraseología comparadas españolas y rumanas. Paremia, 15: 73-81.
Ould Mohamed-Baba, A.S., 2008. Refranero y fraseología hassānī. Instituto de estudios islámicos y del Oriente próximo, Zaragoza.

Paczolay, G., 1997. European Proverbs: In 55 Languages. Veszprémi Nyomda, Veszprém, pp: 527.

Pamies, A. 2001. Modelos icónicos y archimetáforas: algunos problemas metalingüísticos en el ámbito de la fraseología. Language Design, 4: 75-86.

Pamies, A., 2007. El lenguaje de la lechuza. Apuntes para un diccionario intercultural, In: Interculturalidad y lenguaje I. El significado como corolario cultural, Luque J.D.D. and A. Pamies (Eds.), Granada Lingvistica/Método, Granada, pp: 375-404.

Pamies, A., 2008. Comparaison inter-linguistique et comparaison interculturelle. In: Traduction, proverbes et Traductologie, Quitout, M. (Ed.), Éditions L'Harmattan, Paris, pp: 143-156.

Pamies, A., 2011. Motivación cultural y botanismos gastronómicos. In: Uma (re)visão da teoria e da pesquisa fraseológicas, Ortiz Alvarez, M.L. and E. Huelva Unterbäumen (Eds.), Pontes/Universidad Nacional de Brasília, Campinas, pp: 49-68.

Pamies, A., 2013. A metáfora gramatical e as fronteiras (internas e externas) da fraseologia. III Congresso Internacional de Fraseologia e Paremiologia, (IFP' 13), Fortaleza (forthcoming in Revista de Letras.

Pamies. A., 2014. Provérbios fitonímicos e plantas proverbiais. In: Fraseologia and Cia: Entabulando diálogos reflexivos, Silva, S. (Ed.), Pontes, Campinas, pp: 79-104.

Pamies, A., M. Craig and Y. Ghalayini, 2014. Fishing for productive models in the troubled waters of figurative language. In: Phraseology in Multilingual Society, Arsenteva, E. (Ed.), Cambridge Scholars Publishing, Cambridge, pp: 47-70.

Pamies, A., W. Lozano and D. Aguilera, 2004. Fraseología de la borrachera en guaraní y en española. Paremia, 13: 51-64.

Pamies, A., W.C. Lozano and B. Cortina, 2007. Las metáforas del alcohol: contraste translingüístico e intercultural. In: Lenguaje figurado y motivación: una perspectiva desde la fraseología, Álvarez de la Granja, M. (Ed.), Peter Lang, Frankfurt, pp: 273-286.

Pamies, A. and K. Tutáeva, 2010. El árbol como referente linguo-cultural. In: La fraseografía del S. XXI, Pérez, A.M. and C.H. Kaczmarek (Eds.), Frank and Timme, Berlin, ISBN-10: 3865962912, pp: 169-190.

Pascual López, X., 2012. Fraseología española de origen latino y motivo grecorromano. $\mathrm{PhD}$ Thesis, Universitat de Lleida, Spain.

Piirainen, E., 2008. Phraseology and Culture. In: Phraseology: An Interdisciplinary Perspective, Granger, S. and F. Meunier (Eds.), John Benjamins, Amsterdam/Philadelphia, pp: 243-258. 
Piirainen, E., 2010. Widespread idioms in Europe and beyond. Project website: http://www.widespreadidioms.uni-trier.de/ (Accessed on March 2015).

Pollan, M., 2001. The Botany of Desire: A Plant's-Eye View of the World. Random House, New York.

Quartu, B.M., 1993. Dizionario dei modi di dire della lingua italiana. Rizzoli, Milano.

Ribeiro, J., 1984. Frases Feitas. Sercore, Aracaju.

Rodríguez Canto, A., 2000. Producción y comercialización de pitahayas en México. Claridades Agropecuarias (junio).

Rodríguez Valle, N., 2005. Refranes con palabras de origen náhuatl. Revista de literaturas populares, 2: 175-193.

Ruiz de Mendoza, F.J., 1997. Cognitive and pragmatic aspects of metonymy. Cuadernos de Filología Inglesa, 612: 161-178.

Sevilla Muñoz, J., 2008-2011. Refranero Multilingüe. Instituto Cervantes, Madrid.

Simons, G. and L. Simons, 1977. A vocabulary of.Biliau, an Austronesian Language of New Guinea, with Notes on the Development from ProtoOceanic. Working Papers for the Language Variation and Limits to Communication Project, 2.

Staib, B., 1996. L'intersection des relations spatiale et temporelle en français, espagnol et portugais. In: L'organisation lexicale et cognitive des dimensions spatiale et temporelle, Dupuy-Engelhardt, H. and M.J. Montibus (Eds.), CIRLEP-Université, Reims, pp: $175-190$.

Strauss, E., 1994. Dictionary of European Proverbs. Routledge, London, pp: 789.
Tauberschmidt, G., 1995. Sinaugoro Dictionary. Summer Institute of Linguistics, Ukarumpa.

Teliya, V., 1998. Phraseology as a Language of Culture. In: Phraseology: Theory, Analysis and Applications, Cowie, A.P. (Ed.), Oxford University Press, Oxford/New York, pp: 55-78.

Wander, K.F.W., 1867. Deutsches Sprichwörter-Lexikon. Leipzig.

Washburn Hopkins, E., 1905. The fountain of youth. J. Am. Oriental Society, 26: 1-67.

Xatara, C. and M. Seco, 2014. Culturemas em contraste: Idiomatismos do português brasileiro e europeu. Domínios da Lingu@gem, 8: 502-519.

Xenophon, 370 BC [1914]. Cyropaedia. Trs. by Walter Miller. Harvard University Press, Cambridge (MA).

$\mathrm{Xu}, \mathrm{Z}$. and Y. Ying, 2011. Su yu ci dian (俗语词典). Shāng wu yin shu guan (商务印书馆), Beijing.

Yurtbaşi, M., 1996. A dictionary of Turkish Proverbs. Istanbul: author's edition.

Zazzera, 2006. Proverbi e modi di dire napoletani. Newton Compton, Roma.

Zykova, I.V., 2014a. Phraseological Image as an Insight into the Cultural Worldview. In: Phraseologie und Kultur/Phraseology and Culture, Jesenšek, V. and D. Dobrovol'skij (Eds.), Universität, Maribor, pp: 321-336.

Zykova, I.V., 2014b. Phraseological Creativity: From a Linguoculturological Perspective. In: Phraseology in Multilingual Society, Arsenteva, E. (Ed.), Cambridge Scholars Publishing, Cambridge, pp: 92-103. 